\title{
Uluslararası Ceza Mahkemesi Savcısına Kabul Edilebilirlik Değerlendirmesinde Tanınan Geniş Takdir Yetkisinin Kullanımında Ortaya Çıkan Sorunlar
}

\author{
Ebru Demir ${ }^{*}$ (1)
}

Öz

Uluslararası Ceza Mahkemesi kurulduğu tarihten itibaren uluslararası kamuoyunda tartışmalı bir yere sahiptir. Mahkeme, politik saikler doğrultusunda hareket ettiği ve bunun bir sonucu olarak da meşruiyetini yitirdiği yönünde çeşitli eleştirilere muhatap olmaktadır. Mahkemenin bu şekilde eleştirilmesinde ve mahkemenin bir meşruiyet krizine girmesinde Uluslararası Ceza Mahkemesi Savcılarının oynadığı rol büyüktür. Savcının verdiği kararlar ve yaptı̆̆ seçimler, mahkemeye yönelik politikleşme ve meşruiyetini yitirme iddialarını daha da derinleştirmektedir. Makalede, Uluslararası Ceza Mahkemesi Savcılarının olay ve dava seçiminde başvurduğu kabul edilebilirlik şartları incelenmektedir. Bu makaleye göre, mahkemenin kurucu sözleşmesi olan Roma Statüsünde yer alan kabul edilebilirlik şartlarının muğlaklığı ve bu muğlak şartları uygulamada Savcıya tanınan geniş takdir yetkisi, mahkemenin seçici, yanlı ve önyargılı bir şekilde hareket ettiği iddialarının kaynağını oluşturmaktadır. Her ne kadar Savcı, bu şartları şeffaflaştırmak ve uluslararası kamuoyunu olay ve dava seçiminde tarafsız davrandığına dair temin etmek amacıyla çeşitli raporlar yayınlamış olsa da, makalede bu raporların detaylı bir şekilde incelemesi göstermektedir ki kabul edilebilirlik şartları hala muğlaklığını korumaktadır. Ayrıca, makalede incelenen dava örnekleri mahkemenin farklı birimleri arasında da kabul edilebilirlik şartlarına ilişkin anlayış farklılıkları olduğunu net bir şekilde gözler önüne sermektedir. Makale, Uluslararası Ceza Mahkemesi Savcılarının karşılaştıkları güçlükleri göz ardı etmemekte, karşılaştikları ve karşılaşabilecekleri problemleri ve zorlukları kabul etmektedir. Ek olarak makalede, Roma Statüsünün bu konuda muğlak olduğu ve Savcılara kabul edilebilirlik şartlarıyla ilgili olarak yeterince yönlendirme yapmadığı da belirtilmektedir. Bununla birlikte, Savcıların uygulamaları incelendiğinde kabul edilebilirlik kriterlerinin uygulanması aşamasında Uluslararası Ceza Mahkemesi'nin meşruiyetine ve objektifliğine yönelik eleştirileri güçlendiren durumların ortaya çıktı̆ı görülmektedir.

\section{Anahtar Kelimeler}

Uluslararası Ceza Mahkemesi, Uluslararası Ceza Mahkemesi Savcısı, Savcının Takdir Yetkisi, Kabul Edilebilirlik Şartları, Politikleşme, Meşruiyet Krizi

\section{The Problems with the Implementation of the Prosecutorial Discretion at the ICC}

\begin{abstract}
The International Criminal Court's (the ICC or the Court) status and its judicial practices have been controversial since its establishment in 2002. Critics argue that the Court is used by great powers as an instrument to achieve their political objectives and hence it has long lost its legitimacy. The ICC prosecutor has played a key role in aggravating these criticisms. The ICC's legitimacy is further endangered by the Prosecutor's situation and case selection process and the criteria that they have applied. This article argues that the ambiguity embedded in the admissibility conditions in the Rome Statute results in the critique that the ICC is partial, biased and selective. Even though the ICC Prosecutor has recently published various reports in order to make the admissibility conditions transparent, a detailed examination of these reports shows that these criteria are
\end{abstract}

* Sorumlu Yazar: Ebru Demir (Öğr. Gör. Dr.), Ankara Yıldırım Beyazıt Üniversitesi, Hukuk Fakültesi, Milletlerarası Kamu Hukuku Anabilim Dalı, Ankara, Türkiye. E-posta: ebrudemir@ybu.edu.tr ORCID: 0000-0003-2529-3383

Atf: Demir E, "Uluslararası Ceza Mahkemesi Savcısına Kabul Edilebilirlik Değerlendirmesinde Tanınan Geniş Takdir Yetkisinin Kullanımında Ortaya Çıkan Sorunlar" (2021) 79(4) İstanbul Hukuk Mecmuası 1391. https://doi.org/10.26650/mecmua.2021.79.4.0009 
still far from being transparent. The cases analysed in this article manifest that there are different and contrasting understandings of the admissibility conditions even within the ICC itself. This article acknowledges the difficulties that the ICC Prosecutor faces. In order not to overwhelm the ICC with numerous applications, the Prosecutor has to reject some of them. Having admitted that, this article shows that the Prosecutor's practices regarding the admissibility conditions aggravate the criticisms against the ICC's legitimacy and objectivity. The examples in this article illustrate that the admissibility conditions were interpreted in a way which contrasts with the Rome Statute itself.

\section{Keywords}

International Criminal Court, International Criminal Court Prosecutor, Prosecutorial Discretion, Admissibility Conditions, Politicisation, Legitimacy Crisis

\section{Extended Summary}

The Rome Statute, the International Criminal Court's (the ICC or the Court) founding treaty, requires a state to be unwilling or unable (Article 17) to prosecute international crimes for a case to be admissible before the ICC. In addition to unwillingness and inability, a case should also satisfy the gravity threshold set in Articles 17 and 53 of the Rome Statute. Both unwillingness and inability tests and the gravity threshold are ambiguously regulated in the Rome Statute. The ICC Prosecutor has the authority to evaluate a state's criminal justice system in order to determine whether it is sufficient to prosecute international crimes and also to make a decision on whether international crimes committed in some part of the world are grave enough to be prosecuted by the Court. It can therefore be said that the ambiguity embedded in the Rome Statute grants wide discretion to the Prosecutor in interpreting and implementing the admissibility conditions.

This article examines the ways in which the admissibility conditions are used by the Prosecutor during the processes of situation and case selection. The article is divided into two main bodies: in the first part, unwillingness and inability and in the second part the gravity threshold are examined. An examination of the former criteria shows that the Prosecutor accepted the self-referral of a willing and able state in contradiction to both the Article 17 and the complementarity principle in the Rome Statute. In addition, the Prosecutor, in various cases, investigated only the crimes committed by the rebel forces and neglected the crimes perpetrated by the regime forces. As a result of such practices, state parties started to cooperate with the ICC with the purpose of defeating the rebel forces in their territories. Thus, the ICC has become an instrument which states could use for their domestic political gains. In the first section, it is also argued that the Prosecutor's selection of cases mostly from one particular region (Africa) diminishes the objectivity of the Prosecutor. The Prosecutor fails to explain and legitimize the processes of situation and case selection.

In the second part, the definition and the scope of the gravity threshold are scrutinised. Whereas the Rome Statute refers to the gravity in different articles (Articles 17 and 53) as an admissibility condition, there is not enough explanation in 
relation to the meaning of the term. This article argues that the ambiguity in the Rome Statute grants wide discretion to the ICC Prosecutor in interpreting and implementing this criterion. With examples, the article shows that the Prosecutor's interpretation of the gravity threshold is problematic and strengthens the criticisms against the ICC's legitimacy. The article brings forward reports published by the ICC Office of the Prosecutor with the aim of clarifying the criteria used in defining gravity. Whilst these efforts of the Prosecutor are appreciated, it is difficult to say that the reports have concretised the concept. In this section, the cases of Lubanga and Ntaganda are examined. These cases are of importance since they are specifically related to the gravity issue. An examination of these cases shows that there are different and even contrasting understandings in relation to the meaning and the scope of the concept of gravity even within the ICC's bodies.

This article acknowledges the difficulties that the ICC Prosecutor faces. In order not to overwhelm the ICC with numerous applications, the Prosecutor has to reject some of them. During the elimination process, the Rome Statute might also remain unhelpful because of the ambiguity embedded in its wording and the Prosecutor might be given the whole authority and responsibility in the processes of situation and case selection. Having admitted that, this article shows that the Prosecutor's practices regarding the admissibility conditions aggravate the criticisms against the ICC's legitimacy and objectivity. The examples in this article illustrate that the admissibility conditions were interpreted in a way which contrasts with the Rome Statute itself. In order to prove the Court's objectivity and to strengthen its legitimacy, the Prosecutor has to use the discretion granted by the Rome Statute in a more transparent, consistent and impartial way. 


\section{Giriş}

Uluslararas1 Ceza Mahkemesi Eski Savcısı Fatou Bensouda, 9 Aralık 2020 tarihinde İngiliz askerlerinin Irak işgali sırasında işlemiş olduğu iddia edilen suçlara karşı yürüttüğü incelemeyi (preliminary examination) sona erdirme kararı aldı. Savcı yayınladığı raporda, Nisan 2003 - Eylül 2003 tarihleri arasında İngiliz askerlerinin Irak’ta gerçekleştirdiği ölümlerin, Roma Statüsünün 8(2)(a)(i) ve 8(2)(c)(i) maddeleri kapsamında savaş suçu olarak değerlendirilmesi için makul bir temel olduğunu ortaya koydu. ${ }^{1}$ Savcı kendisine ulaştırılan bilgilerin ışığında en az 1071 Iraklı tutuklunun işkence veya insanlık dışı muameleye maruz kaldığına, 319 kişinin öldürüldüğüne ve 21 tutukluya da tecavüz edildiğine yönelik iddialar bulunduğunu raporunda belirtmektedir. ${ }^{2}$ Bununla birlikte, Savc1, 2010 y1lında İngiltere'nin kurmuş olduğu Irak Tarihi İddialar Ekibi'nin (Iraq Historic Allegations Team) - her ne kadar etkili bir şekilde çalışıp çalışmadığı tartı̧̧maya açık olsa da ${ }^{3}$ - kabul edilebilirlik için gerekli olan isteksizlik şartını ortadan kaldırdığını öne sürmektedir. ${ }^{4}$ Irak Tarihi İddialar Ekibi'nin etkili bir kurum olmadığı ve failleri uluslararası mahkemeler önünde yargılanmaktan korumak amacıyla hareket ettiği iddialarının Savcıya iletilmesine rağmen, Savcı bu korumanın bireysel düzeyde var olmasının sistemsel ve geniş çapta bir koruma olarak değerlendirilemeyeceğini iddia etmiştir. ${ }^{5}$ Sonuç olarak, kurumun İngiliz askerlerini yargılamada istekli olduğu kanaatine varmıştır.

Uluslararas1 Ceza Mahkemesi Savcısının bu kararına yönelik olarak akademisyenler çeşitli eleştirilerde bulunmuşlardır. Andreas Schueller, Birleşik Krallık'ın, askerlerinin yargı önünde hesap vermesini önlemeye yönelik çabalarının bu devletin yakın ve uzak (kolonyal) tarihine bakıldığında görülebileceğini, dolayısıyla sistematik bir korumanın Birleşik Krallık tarafından geleneksel olarak uygulanan bir metot olduğunu öne sürmüştür. ${ }^{6}$ Buna ek olarak, Schueller, Uluslararas1 Ceza Mahkemesi'nin bu gibi koruma kalkanı (shield) kurumları "devletlerin kendi üzerine düşen yükümlülüğü yerine getirmesi” şeklinde yorumlamasının, diğer güçlü devletleri de benzer kurumlar yaratmaya teşvik edeceğini ileri sürmüştür. ${ }^{7}$ Kevin Jon Heller, kararda Savcının başvurduğu güvenilir kaynakların, Irak Tarihi İddialar Ekibi'nin istekli bir şekilde soruşturma yürüttüğüne inanmayı çok zor bir hale getirdiğini belirtmiştir. ${ }^{8}$ Heller, Uluslararası Ceza Mahkemesi'nin kurucu anlaşması

\footnotetext{
Uluslararası Ceza Mahkemesi Savc1lık Makamı, 'Situation in Iraq/UK: Final Report' (Aralık 2020)<https://www.icc-cpi. int/itemsDocuments/201209-otp-final-report-iraq-uk-eng.pdf > paragraf 2, Erişim Tarihi 14 Aralık 2020.

ibid paragraf 24.

ibid paragraf 499-500.

ibid paragraf 500 .

ibid paragraf 486-487.

' Andreas Schueller, 'The ICC, British War Crimes in Iraq and a Very British Tradition' (Aralık 2020) <https://opiniojuris. org/2020/12/11/the-icc-british-war-crimes-in-iraq-and-a-very-british-tradition/>. Erişim Tarihi 14 Aralık 2020.

ibid.

8 Kevin Jon Heller, 'The Nine Words That (Wrongly) Doomed the Iraq Investigation' (Aralık 2020) <http://opiniojuris. org/2020/12/10/the-nine-words-that-wrongly-doomed-the-iraq-investigation/>. Erişim Tarihi 14 Aralık 2020.
} 
olan Roma Statüsüne göre Savcının dava açması için gereken şartları Savcının kendi yürüttüğü soruşturmanın zaten sağladığına işaret etmektedir. ${ }^{9}$ Karar, Uluslararası Ceza Mahkemesi'ne ve özellikle de Savcının uygulamalarına yönelik problemler içeren ve akademik literatürde tartışmalar yaratacak bir karardır.

Savcinın bu ve buna benzer şekilde tartışma yaratan kararları, bu makaleye göre, Roma Statüsünde yer alan kabul edilebilirlik şartlarının muğlaklığı ve bu muğlak şartları uygulamada Savcıya tanınan geniş takdir yetkisi sonucu ortaya çıkmaktadır. Uluslararası Ceza Mahkemesi'nin içinde bulunduğu meşruiyet krizine dair geniş bir literatür olmasına rağmen, Savcının bu meşruiyet krizindeki rolüne dair nispeten daha az araştırma bulunmaktadır. Bu makale, mahkemenin politik bir kurum olarak algılanmasında ve sonuç olarak da meşruiyetinin sarsılmasında, Savcının verdiği kararların ve yaptığı seçimlerin rolünü incelemeyi amaçlamaktadır. Makale, Roma Statüsü tarafından Savcıya tanınan geniş takdir yetkisinin meşruiyet krizlerini derinleştirecek şekilde kullanıldığını savunmaktadır. Uluslararası Ceza Mahkemesi’nin meşruiyetine yönelik tartışmaların güncelliği bu makaleyi zamanlı ve gerekli kılmaktadır.

Makale ilk olarak kabul edilebilirlik şartlarından olan isteklilik ve yeterlilik kriterlerini inceleyecektir. Bu iki kriter, Roma Statüsünde düzenlenmiş olup bir olayın mahkemenin yarg1 yetkisi kapsamında kabul edilip edilmeyeceğine dair Savcının yapacağı değerlendirmenin temelini oluşturur. Bir sonraki bölümde ise yine Roma Statüsünde düzenlenmiş olan vahamet (gravity) kriteri ele alınacaktır. Vahamet kriteri Roma Statüsünde tamamen muğlak bir şekilde düzenlenmiş olup, mahkemeye yapılabilecek çok sayıdaki başvuru arasından Savcının "vahim olmayanları" elemesine yardımcı olmak amacıyla Statüye konulmuştur. Makalede, sırasıyla bu kabul edilebilirlik şartlarının Savcı tarafından nasıl problemli bir şekilde kullanıldığı gösterilecek, örnek olay ve davalar ile bu argüman desteklenecektir.

\section{Kabul Edilebilirlik Şartlarının Uluslararası Ceza Mahkemesi Savcısı Tarafından Kullanımında Ortaya Çıkan Problemler: İsteklilik ve Yeterlilik Kriterleri}

Uluslararası Ceza Mahkemesi'ne yönelik eleştiriler mahkemenin seçici, yanlı ve önyargılı bir biçimde soruşturma yürüttüğü ve bu nedenle politik bir kurum haline dönüştüğü şeklindedir. Sri Lanka, Filistin toprakları, Afganistan ve Suriye’deki insan hakları ihlallerine karşı Uluslararası Ceza Mahkemesi’nin yanıtsız kalması, mahkemenin Birleşmiş Milletler Güvenlik Konseyi üyelerinin politik ve stratejik

ibid. Aynı yazarın kararla ilgili bir başka eleştirisi için, bakınız: Kevin Jon Heller, 'Article $18 \overline{\text { and the Iraq Declination' }}$ (Aralık 2020) <http://opiniojuris.org/2020/12/12/article-18-and-the-iraq-declination/>. Erişim Tarihi 14 Aralık 2020. 
çıkarları doğrultusunda hareket ettiğine yönelik eleştirilere yol açmıştır. ${ }^{10}$ İnsan Hakları İzleme Örgütü, mahkemenin politik amaçlar için kullanılmaması ve bağımsız ve tarafsız bir şekilde yetkisini kullanması gerektiği yönünde uyarılarda bulunmuştur. ${ }^{11}$ Örgüt, Uganda, Orta Afrika Cumhuriyeti ve Kongo Demokratik Cumhuriyeti örneklerinde, hükümet yetkililerinin işlediği suçların mahkemece dikkate alınmamasının mahkemenin bağımsızlığını sarstığını dile getirmiştir. ${ }^{12}$ Bununla birlikte, bazı araştırmacılar Uluslararası Ceza Mahkemesi'ne yönelik bu eleştirileri haksız bulmuş ve mahkemenin yanıtsız kaldığ "başarılı" bir şekilde ele aldığ davaları etkilememesi gerektiğini iddia etmişlerdir. ${ }^{13}$ Örneğin, mahkemenin Suriye'deki etkisizliğinin mahkemenin Afrika'da yürüttüğü soruşturma ve kovuşturmalara gölge düşürmemesi gerektiği savunulmuştur. ${ }^{14}$

Bazı yazarlar daha da ileri giderek, en ağır suçların çok sayıda faili olacağından, Uluslararası Ceza Mahkemesi'nin seçici olmasının bir gereklilik olduğunu öne sürmüşlerdir. ${ }^{15}$ Bazı yazarlar ise, Uluslararası Ceza Mahkemesi'nin işleyebilmesi için Savcının taraf devletlerle iş birliğinin zorunlu olduğunun altını çizmişlerdir. ${ }^{16}$ Taraf devletlerle iş birliği olmadığında, Savcının davayı yürütmekte güçlüklerle karşı karşıya kalacağ 1 ve görevini yerine getirmesini engelleyen manilerin ortaya çıkacağı öne sürülmüştür. ${ }^{17}$ Dolaylı olarak Uluslararası Ceza Mahkemesi'ne taraf olmayan veya taraf olduğu halde iş birliği yapmayan devletlere karşı soruşturma ve kovuşturma yürütülmemesinin, mahkemenin seçici, yanlı ve önyargıll olduğu şeklinde yorumlanmaması gerektiği iddia edilmiştir. Bu açıklama iki açıdan problemlidir. Öncelikle, Uluslararası Ceza Mahkemesi'nin kendisiyle iş birliği yapan taraf devletlere karşı açmış olduğu davalarda da taraflı ve yanlı hareket ettiği görülmektedir (Uganda ve Kongo Demokratik Cumhuriyeti örneklerinde olduğu gibi). Dolayısıyla, iş birliği olduğunda dahi mahkemenin sorunsuz, tarafsız ve bağımsız çalışabildiği iddia edilememektedir. İkinci olarak ise, mahkemenin soruşturma yürütmeme ya da yürüttüğü soruşturmayı sonlandırma kararı aldığı için eleştirildiği davalarda (örneğin İngiltere-Irak olayında), taraf devletin iş birliğinin olmadığı iddia edilememektedir. Bu sebeple, Savcının soruşturma yürütmemeyi tercih ettiği tüm durumlarda, iş birliği eksikliğinin neden olarak gösterilmesi doğru değildir.

10 Alana Tiemessen, 'The International Criminal Court and the Politics of Prosecutions' (2014) $18 \overline{\text { The International Journal }}$ of Human Rights 444, 449.

11 Human Rights Watch, 'ICC: New Prosecutor Takes Reins' (13 June 2012)<https://www.hrw.org/news/2012/06/13/icc-newprosecutor-takes-reins>. Erişim Tarihi 14 Aralık 2020.

12 ibid.

13 Destaw A Yigzaw, 'The International Criminal Court: Biased Against Africa or Weak Towards the Powerful?' (2017) 43 North Carolina Journal of International Law 204, 235.

14 ibid 236.

15 Hitomi Takemura, 'Big Fish and Small Fish Debate-An Examination of the Prosecutorial Discretion' (2007) 7 International Criminal Law Review 677, 683.

16 Cale Davis, 'Political Considerations in Prosecutorial Discretion at the International Criminal Court' (2015) 15 International Criminal Law Review 170 .

17 ibid 173. 
Mahkemenin taraflı bir kurum olarak düşünülmesinde hangi faktörlerin etkili olduğu sorulması gereken önemli bir sorudur. ${ }^{18}$ Mahkemenin taraflı olduğuna yönelik eleştirilerin temelinde seçilen olayların yanı sıra seçilmeyen, yanıtsız ve kayıtsız kalınan olaylar da yatmaktadır. Bu bağlamda mahkemeye yöneltilen eleştirilerden biri de mahkemenin yanlı yahut seçici adalet (selective justice) sağlayan bir kuruma dönüşmesidir. Afrika Birliği Komisyonu Başkanı Jean Ping'in bu mevzu hakkındaki görüşleri Afrika Birliği’nin tutumunu özetler niteliktedir:

"Uluslararası hukuk, güçlü devletlerin zayıf devletleri dövdükleri büyük bir sopa olmamalıdır. Seçici adalete karşıyız. Eğer adil olunacaksa, [örneğin] Gürcistan Cumhurbaşkanı da adaletle yüzleşmelidir." 19

Dava seçimindeki yanlılık iddiaları, Uluslararası Ceza Mahkemesi Savcısının seçtiği davalara ek olarak seçmediği olaylar üzerinden de güç kazanmaktadır. İngiliz askerlerinin Irak'ta sebep oldukları iddia edilen ölümler hakkında mahkemede soruşturma açılmaması uluslararası kamuoyunda rahatsızlık meydana getirmiş ve Uluslararası Ceza Mahkemesi Savcısına verilen geniş inisiyatifin politik saikler doğrultusunda kullanıldığına dair kanı yaratmıştır. ${ }^{20}$ Bunun sonucunda ise mahkemenin, hem seçilen davalardaki "faillerin" hem de seçilmeyen "olaylardaki" mağdurların önemsenmediği bir platforma dönüştüğü öne sürülmüştür. ${ }^{21}$

William A. Schabas, Uluslararası Ceza Mahkemesi'nin muhatap olduğu eleştirilerin mahkemenin sui generis niteliğinden kaynaklandığını düşünmektedir. ${ }^{22}$ İlk kurulan uluslararası ceza mahkemelerinden olan ve İkinci Dünya Savaşı sonrası Nazi liderlerini yargılamak için 1945'te kurulan Nürnberg Uluslararası Askeri Ceza Mahkemesi'nde Sovyetler Birliği, Amerika Birleşik Devletleri, Fransa ve Birleşik Krallık vatandaşı dört savcı görev yapmaktaydı. Schabas'ın belirttiği üzere, bu savcılar bağımsız olarak değil, kendi hükümetlerinin temsilcileri olarak görevlerini yürütmekteydiler. ${ }^{23}$ Yapılan bir çalışma, Nürnberg Uluslararası Askeri Ceza Mahkemesi’ndeki savcıların, istihbarat ajanları arasından seçildiğini ve göreve gelen savcıların kendi temsil ettikleri devletlerin istihbarat servisleriyle olan yakın ilişkisini gözler önüne sermektedir. ${ }^{24}$

18 Geoff Dancy and others, 'What Determines Perceptions of Bias toward the International Criminal Court? Evidence from Kenya' (2020) 64 Journal of Conflict Resolution 1443, 1448.

19 Ifeonu Eberechi, "'Rounding Up the Usual Suspects": Exclusion, Selectivity, and Impunity in the Enforcement of International Criminal Justice and the African Union's Emerging Resistance' (2011) 4 African Journal of Legal Studies 51, 51. (yazarın çevirisi)

20 Celestine Nchekwube Ezennia, 'The Modus Operandi of the International Criminal Court System: An Impartial or a Selective Justice Regime?’ (2016) 16 International Criminal Law Review 448, 460.

21 ibid 477.

22 William A Schabas, 'Prosecutorial Discretion v. Judicial Activism at the International Criminal Court' (2008) 6 Journal of International Criminal Justice 731.

23 ibid 732.

24 Michael Salter, Nazi War Crimes, US Intelligence and Selective Prosecution at Nuremberg: Controversies Regarding the Role of the Office of Strategic Services (1st edn, Routledge-Cavendish 2007). 
Birleşmiş Milletler Güvenlik Konseyi, ad hoc mahkemelerin kuruluşu aşamasında, dava seçimini gerekçelendirme yükümlülüğü altında olmamakla beraber bu durum ad hoc mahkeme savcıları için de gerekli değildi. ${ }^{25}$ Ad hoc mahkemeler zaten spesifik bir bölge ya da ülkede işlenen uluslararası suçları kovuşturmak amacıyla kurulduklarından, dava seçimi yapmaları söz konusu değildir. Dolayısıyla 1990'larda kurulan ad hoc uluslararası ceza mahkemeleri (Eski Yugoslavya Uluslararası Ceza Mahkemesi ve Ruanda Uluslararası Ceza Mahkemesi) Savcıları da dava seçme gibi bir yükümlülükle karşı karşıya kalmadılar. ${ }^{26}$ Kendisine yönlendirilen "olaylar" arasından seçim yapma görevi uluslararası ceza hukukunda ilk kez Uluslararası Ceza Mahkemesi Savcısının elinde bulundurduğu bir yetkidir.

Mahkemenin kurulma aşamasında, mahkemenin yarg1 yetkisinin hangi merciler tarafından etkin hale getirilebileceği (trigger mechanisms) en çok tartışılan konulardan biri olmuştur. ${ }^{27}$ Sonuç olarak, her ne kadar Roma Statüsünde mahkemenin yarg1 yetkisinin kullanılmasında Savcı dişında hem taraf devletlerin (Madde 13(a)) hem de Birleşmiş Milletler Güvenlik Konseyi'nin yetkileri bulunsa da (Madde 13(b)), bu durum Savcının yetki alanını daraltan bir durum değildir. John Dugard'in belirttiği üzere, Roma Statüsüne taraf devletlerin veya Güvenlik Konseyi'nin başvuru yapmaları halinde, Savcı dava açmakla yükümlendirilmemektedir. ${ }^{28}$ Savc1, taraf devletlerin veya Güvenlik Konseyi’nin kendisine başvurması durumunda da nihai söz sahibi konumundadır. Dolayısıyla, Dugard'in da ortaya koyduğu üzere, taraf devletlerin veya Güvenlik Konseyi'nin başvuruları Savcının kendi tarafından (proprio motu) açılan davalardan, bu açıdan bakıldığında, hiçbir fark taşımamaktadır. ${ }^{29}$ Davayı açıp açmama yetkisi son kertede yine Uluslararası Ceza Mahkemesi Savcısındadır. Güvenlik Konseyi'nin bir olayı Uluslararası Ceza Mahkemesi’ne göndermesi (Madde 13(b)), bu olayın mahkeme tarafından nasıl değerlendirileceğini belirleyemez. ${ }^{30}$

$\mathrm{Bu}$ makaleye göre, mahkemeye yöneltilen taraflı bir şekilde dava seçtiği eleştirilerinin temelinde Uluslararası Ceza Mahkemesi Savcısının olay ve dava seçiminde başvurduğu kriterlerdeki muğlaklık yatmaktadır. Roma Statüsüne göre kabul edilebilirlik şartları (admissibility conditions) Madde 17'de düzenlenmiştir. ${ }^{31}$

25 William A Schabas, 'Victor's Justice: Selecting "Situations" at the International Criminal Court' (2010) 43 The John Marshall Law Review 535, 543.

26 ibid 543-544. Ad hoc mahkemeler ile daimi Uluslararası Ceza Mahkemesi üzerine karşılaştırmalı bir analiz için, bakınız: Ezeli Azarkan, 'Uluslararası Ceza Mahkemesi ile Eski Yugoslavya Uluslararası Ceza Mahkemesinin Karşıllaştırmalı Analizi’ (2004) 24 Milletlerarası Hukuk ve Milletlerarası Özel Hukuk Bülteni 211.

27 Yusuf Aksar, 'Uluslararası Ceza Mahkemesi ve Amerika Birleşik Devletleri (ABD)' (2003) 52 Ankara Üniversitesi Hukuk Fakültesi Dergisi 125, 130.

28 John Dugard, 'Palestine and the International Criminal Court: Institutional Failure or Bias?' (2013) 11 Journal of International Criminal Justice 563, 563.

29 ibid.

30 Elif Uzun, 'Milletlerarası Ceza Mahkemesi Düşüncesinin Tarihsel Gelişimi ve Roma Statüsü' (2003) 2 Sosyal Bilimler Dergisi 25, 39.

31 Uluslararası Ceza Mahkemesi Roma Statüsü (1998) <http://sorular.rightsagenda.org/Uploads/UCM\%20MEV/Roma\%20 Statüsü.pdf>. Madde 17, Erişim Tarihi 14 Aralık 2020. 
Madde 17'deki koşulların muğlaklığına ve neden oldukları politikleşme eleştirilerine dikkatle eğilmek gerekir. Taraf devletin dava açmakta isteksiz olması veya davayı açmaya yeterli donanımının ve imkanının olmaması kriterleri hem mahkemeyi hem de Savcıyı politik kararlar vermekle karşı karşıya bırakmaktadır. ${ }^{32}$ Eski Yugoslavya Uluslararası Ceza Mahkemesi eski Savcısı Lousie Arbour'un belirttiği üzere, mahkemeye davaların kabul edilebilirlik şartları, bir başka devletin ulusal hukuk sistemini yargılamayı zorunlu kılmaktadır. ${ }^{33}$ Bir taraf devletin hukuk sisteminin, uluslararası bir suçu yargılamaya yetecek kapasitede olup olmadığının araştırılması tamamen hukuki bir değerlendirme teşkil etmez. Benzer şekilde, bir taraf devletin uluslararası suçları kovuştururken bu suçların yeterli vahamete erişmediğini tespiti, Uluslararası Ceza Mahkemesi Savcısı tarafından isteksizlik olarak anlaşılabilir. Başka bir ifadeyle, taraf devletler kendi sınırları dahilindeki olayların uluslararası suç niteliğinde olmadığını ulusal mahkemelerinde tespit ettiklerinde, bu, Savcı nezdinde, Madde 17(1)'deki isteksizlik kriterine karşılık gelebilmekte ve bu yönde değerlendirilebilmektedir.

İsteksizlik ve yetersizlik kriterlerinin Savcı tarafından pratikteki uygulaması mahkemenin politikleşme eleştirilerini güçlendirmektedir. Uluslararası Ceza Mahkemesi Savcısı, davaların ve soruşturmaların çoğunu Afrika devletlerinin oluşturmasını gerekçelendirmekte ve meşrulaştırmakta zorluklar yaşamaktadır. Uluslararası Ceza Mahkemesi'nin kurucu sözleşmesi olan Roma Statüsüne taraf 123 devletin 33'ünü Afrika devletleri oluşturmaktadır. Bu, üye devletlerin yaklaşık yüzde 25 'inin Afrika devletleri olduğunu gösterir. Bununla birlikte, Kasım 2020 itibariyle Uluslararası Ceza Mahkemesi’ndeki 13 soruşturmanın 10'u Afrika devletlerine karşı yürütülmektedir. ${ }^{34} \mathrm{Bu}$, şu anki soruşturmaların yaklaşık yüzde 75 'inin Afrika devletlerine karş1 yürütüldügünü gösterir. ${ }^{35}$ Roma Statüsü Madde 17'de yer alan kabul edilebilirlik şartları, davaların büyük çoğunluğunun Afrika devletlerine karşı olmasını açıklamakta yetersiz kalmaktadır.

Mahkemenin çoğunlukla Afrika' daki devletleri soruşturmasını, Afrika devletlerinin altyapı ve teknik imkanlar bakımından bu tür suçları yargılayabilecek yeterlilikte kapasitelerinin olmaması ile açıklayan araştırmacılar bulunmaktadır. ${ }^{36} \mathrm{Bu}$ makale,

32 Allison Marston Danner, 'Enhancing the Legitimacy and Accountability of Prosecutorial Discretion at the International Criminal Court' (2003) 97 American Journal of International Law 510, 517.

33 ibid.

34 Uluslararası Ceza Mahkemesi, ‘The Court Today', ICC-PIDS-TCT-01-114/20_Eng (Kasım 2020)<https://www.icc-cpi.int/ iccdocs/pids/publications/thecourttodayeng.pdf> Erişim Tarihi 14 Aralık 2020.

35 Kasım 2020 itibariyle Uluslararası Ceza Mahkemesinde 13 soruşturma bulunmaktadır: Uganda, Kongo Demokratik Cumhuriyeti, Orta Afrika Cumhuriyeti, Orta Afrika Cumhuriyeti II, Darfur (Sudan), Kenya, Libya, Fildişi Sahili, Mali, Burundi, Gürcistan, Bangladeş/Myanmar ve Afganistan.

Kasım 2020 itibariyle Uluslararası Ceza Mahkemesinde 10 hazırlık incelemesi/soruşturması (preliminary examinations) bulunmaktadır: Bolivya, Kolombiya, Gine, Irak, Nijerya, Filistin, Filipinler, Ukrayna ve Venezuela (I ve II). Bakınız: Uluslararası Ceza Mahkemesi, ‘The Court Today', ICC-PIDS-TCT-01-114/20_Eng (Kasım 2020)<https://www.icc-cpi.int/ iccdocs/pids/publications/thecourttodayeng.pdf>. Erişim Tarihi 14 Aralık 2020.

36 Yigzaw (n 13) 235-236. 
bu görüşe karşı çıkmakta ve seçici bir şekilde sağlanan adaletin adalet olmadığını savunmaktadır. Mahkemenin teknik imkanları zayıf olan devletlerin yetkililerine karşı dava yürütmesi, mahkemenin uluslararası niteliğini gölgelemektedir. Mahkemenin belli bir bölgeye odaklanması mahkemenin evrensel bir şekilde adalet sağladığına yönelik inancı zedelemektedir. ${ }^{37}$ Uluslararası Ceza Mahkemesi'nin uluslararası suçları kovuşturmakta yetersiz (unable) devletleri ve sadece bu tür devletleri yargılayan bir mahkemeye dönüşmesi, mahkemenin "en zayıf [devletlerin] peşinde koşan bir mahkeme" karakterine bürünmesine yol açmıştır. ${ }^{38} \mathrm{Bu}$ durum, Afrikalıların "en ağır suçları işledikleri” için değil, bu ağır suçları yargılamak amacıyla gerekli altyapı ve teknik imkanlara sahip olmadıkları için Uluslararası Ceza Mahkemesi'nde yargılandıkları sonucunu doğurmaktadır. ${ }^{39}$

Mahkemenin en zayıf devletleri yargılayan bir mahkemeye dönüşmesi kendisine yönelik politikleşme eleştirilerini güçlendirmekte ve bunun da ötesinde mahkemenin kolonyal nitelikte olduğu eleştirilerini doğurmaktadır. ${ }^{40}$ Ruanda eski Cumhurbaşkanı Paul Kagame eleştirilerinde mahkemenin "en zayıf" devletlerin peşine düşen bir mahkeme olmasını kolonyalizm ile şu şekilde ilişkilendirmektedir:

"Uluslararası Ceza Mahkemesi geçmişteki tüm adaletsizlikleri, kolonyalizmi, emperyalizmi farklı formlarda geri getirmektedir. [...] Güçsüz ve zayıf iseniz, kendinizi asmanız için bir ip her zaman vardır ve Uluslararası Ceza Mahkemesi Afrikalı zayıf devletler için [bu amaçla] yapılmıştır." ${ }^{41}$

Benzer yönde açıklamayı Sudan eski Cumhurbaşkanı Omar al-Bashir de yapmıştır:

"Afrika'da, Uluslararası Ceza Mahkemesi Afrikalı liderleri korkutma amaciyla kurulmuş kolonyalizmin yeni yüzü olarak görülmektedir. Eğer Uluslararası Ceza Mahkemesi tarafından yargılanan kişilere bakarsanız, hepsinin Afrikalı ve özellikle de hepsinin Batının politik baskılarına karşı çıkan şahıslar olduğunu görebilirsiniz." ${ }^{42}$

37 Dire Tladi, 'The African Union and the International Criminal Court: The Battle for the Soul of International Law' (2009) 34 South African Yearbook of International Law 57, 69.

38 Edwin Bikundo, 'The International Criminal Court and Africa: Exemplary Justice' (2012) 23 Law and Critique 21, 28.

39 ibid.

40 Uluslararası Ceza Mahkemesinin kolonyalist bir karaktere sahip olup olmadığına yönelik tartışmaları içeren literatür için, bakınız: Ann Sagan, 'African Criminals/African Victims: The Institutionalised Production of Cultural Narratives in International Criminal Law' (2010) 39 Millennium: Journal of International Studies 3; Kirsten Ainley, 'The International Criminal Court on Trial' (2011) 24 Cambridge Review of International Affairs 309; Patryk I Labuda, 'The International Criminal Court and Perceptions of Sovereignty, Colonialism and Pan-African Solidarity' (2014) 20 African Yearbook of International Law Online 289; Brendon J Cannon, Dominic R Pkalya and Bosire Maragia, 'The International Criminal Court and Africa: Contextualizing the Anti-ICC Narrative' (2016) 2 African Journal of International Criminal Justice 6; Laurence R Helfer and Anne E Showalter, 'Opposing International Justice: Kenya's Integrated Backlash Strategy against the ICC' (2017) 17 International Criminal Law Review 1; Geoffrey Lugano, 'Counter-Shaming the International Criminal Court's Intervention as Neocolonial: Lessons from Kenya’ (2017) 11 International Journal of Transitional Justice 9.

41 Nation, 'Kagame Tells Why He Is Against ICC Charging Bashir' (Kigali, Ağustos 2008) <https://nation.africa/kenya/news/ africa/kagame-tells-why-he-is-against-icc-charging-bashir--552248>. (yazarın çevirisi) Erişim Tarihi 14 Aralık 2020

42 France 24, 'Sudan's Bashir Blasts ICC's "New Face of Colonialism"' (27 May 2013) <https://www.france24.com/ en/20130527-african-union-icc-justice-sudan-bashir-kenya-kenyatta>. (yazarın çevirisi) Erişim Tarihi 14 Aralık 2020. 
Mahkemenin zayıf devletlerin yetkililerini yargılayan bir kuruma dönüştüğü, politik ve kolonyal bir kurum olduğu yönündeki eleştirilere cevaben mahkemenin tamamlayıcılık (complementarity) prensibi doğrultusunda hareket etmesi gerektiğine yönelik fikirler vardır. Roma Statüsü Madde 1'de belirtildiği üzere, Uluslararası Ceza Mahkemesi çok ciddi suçları işleyen kişiler üzerinde yargı yetkisine sahip bir mahkemedir ve devletlerin ulusal yarg1 yetkisini tamamlayıcı niteliktedir." ${ }^{33}$

Bu doğrultuda, taraf devletlerin Roma Statüsünün imzalanması aşamasında kendi egemenlik haklarını zedelemeyecek bir mahkeme kurmayı tasavvur ettikleri kesindir. Line Engbo Gissel' in kapsamlı çalışması, Roma Statüsünün hazırlanması aşamasında Afrika'daki devletlerin Birleşmiş Milletler Genel Kurulu'nda nasıl bir mahkeme yaratmak istediklerine dair sundukları görüşleri sistematik olarak analiz etmiştir. ${ }^{44}$ $\mathrm{Bu}$ faydalı çalışma göstermektedir ki Afrikalı diplomatlar uluslararası bir ceza mahkemesini ulusal mahkemelerden hiyerarşik olarak katiyen üstte görmemişlerdir. ${ }^{45}$ Uluslararası bir mahkemenin ancak ve ancak ulusal mahkemelerin ağır insan hakları ihlallerini kendilerinin soruşturacak donanımları olmadığında, suçların cezasız kalmasını (impunity) önleme amacıyla işlerlik kazanmasını istemişlerdir. ${ }^{46}$ Statü, hem giriş k1smında ${ }^{47}$ hem de Madde 1'de görüldügüü üzere, Afrika' daki devletlerin bu istek ve endişelerini dikkate alarak tasarlanmıştır.

Statü genel olarak devletlerin egemenliğini göz önünde bulunduran hükümler içermektedir. ${ }^{48}$ Bu nedenle, Uluslararası Ceza Mahkemesi'nin devletlerin egemenlik haklarını kısıtlayan veya bu hakların önüne geçen değil, bu hakları tamamlayıcı nitelikte işlev gören bir kurum olması beklenir. ${ }^{49}$ Pozitif tamamlayıcılık ilkesi Roma Statüsünde yer alan bir ilke değildir, ancak Savcılık tarafından 2006 ve 2010

43 Uluslararası Ceza Mahkemesi Roma Statüsü (n 31)

44 Line Engbo Gissel, 'A Different Kind of Court: Africa's Support for the International Criminal Court, 1993-2003' (2018) 29 European Journal of International Law 725.

45 ibid 741.

46 ibid.

47 Uluslararası Ceza Mahkemesi Roma Statüsü (n 31). Giriş, paragraf 10.

48 Ali Sahin Kılıç, 'Uluslararası Ceza Mahkemesi ve Devletlerin Egemenliği Üzerine Ulusal Egemenlik Odaklı Bir İnceleme' (2009) 58 Ankara Üniversitesi Hukuk Fakültesi Dergisi 615, 639.

49 Öte yandan, bazı yazarlar tarafindan Roma Statüsündeki tamamlayıcılık ilkesi mahkemenin evrensel yargı yetkisine sahip olmasının önünde bir engel olarak değerlendirilmiştir. Arzu Alibaba, 'Uluslararası Ceza Mahkemesinin Kuruluşu' (2000) 49 Ankara Üniversitesi Hukuk Fakültesi Dergisi 181, 183-184. 
raporlarında yorumlama yoluyla geliştirilmiş ${ }^{50}$ ve literatürde de kabul görmüştür. ${ }^{51}$ Bu ilkeye göre, Uluslararası Ceza Mahkemesi, Afrika'daki devletler gibi, uluslararası suçları yargılamaya muktedir altyapı ve teknik uzmanlıkları olmayan devletlerle iş birliği yürüterek bu suçların ulusal mahkemelerde yargılanmasına yardım etmelidir. ${ }^{52}$ Ancak, mahkemenin politikleşme iddialarını azaltabileceği amacıyla literatürde geliştirilmiş olan bu prensibi, Uluslararası Ceza Mahkemesi'nin benimsediği söylenemez. Uygulamaya bakıldığında, taraf devletlerin hukuk sistemlerinin geliştirilmesinin ve kendi ulusal mahkemelerinin öncelikli hale getirilmesinin Uluslararası Ceza Mahkemesi’nin dikkate aldığı bir prensip olmadığı görülür. Tamamlayıcılık ilkesinin ihmali ve Uluslararası Ceza Mahkemesi'nin kendisini adalet sağlamada öncelikli (primary) kurum olarak - ki bu durum Roma Statüsünün ihlali anlamına gelse dahi - sunmasını Branch isabetli bir şekilde şöyle değerlendirmiştir:

“Uluslararası Ceza Mahkemesi toplumlara adaleti ‘uluslararası kamuoyunun' ellerinden beklemelerini ve adaleti sağlamak için kendi içlerinde örgütlenmemelerini öğretmektedir; hatta, küresel adaletin sağlanması adına toplumlar kendi kuruluşlarını dahi kapatabilir. Adalet ancak dış kaynaklı (foreign) kurum ve kuruluşlarca sağlanabilecek bir ürün haline getirilmiştir [...]. Uluslararası Ceza Mahkemesi, bu şekilde, tüm insanlık için [kendisine karş1] politik bir bağımlılık teşvik etmektedir." ${ }^{53}$

Mahkemenin çoğunlukla Afrika devletlerini soruşturmasını Afrika devletlerinin altyapı ve teknik imkanlar bakımından yetersiz olmasıyla açıklamak pratikteki uygulamalara da ters düşmektedir. Uganda davası bu konuya verilebilecek yerinde bir örnek olacaktır. 2003 yılında Uganda Hükümeti, Tanrı'nın Direniş Ordusunun (Lord's Resistance Army-LRA) işlediğini iddia ettiği suçları kovuşturması için Uluslararası Ceza Mahkemesi’nin önüne hükümet olarak kendisi olay getirmiştir (self-referral). Payam Akhavan'ın belirttiği üzere, hukuki açıdan bakıldığında, mahkemenin Tanrı'nın Direniş Ordusu üzerinde yargı yetkisi olduğu kesindir. ${ }^{54} \mathrm{Bu}$

50 Bakınız Uluslararası Ceza Mahkemesi Savcılık Makamı, 'Report on the Activities Performed During the First Three Years (June 2003 - June 2006)' (Eylül 2006) <https:/www.icc-cpi.int/nr/rdonlyres/d76a5d89-fb64-47a9-9821-725747378ab2/143680/ otp_3yearreport20060914_english.pdf> Erişim Tarihi 14 Aralık 2020 ve Uluslararası Ceza Mahkemesi Savcıllk Makamı, 'Prosecutorial Strategy 2009 - 2012' (Şubat 2010) <https://www.icc-cpi.int/NR/rdonlyres/66A8DCDC-3650-4514-AA62D229D1128F65/281506/OTPProsecutorialStrategy20092013.pdf > Erişim Tarihi 14 Aralık 2020.

51 William W Burke-White, 'Implementing a Policy of Positive Complementarity in the Rome System of Justice' (2008) 19 Criminal Law Forum 59; William W Burke-White, 'Proactive Complementarity: The International Criminal Court and National Courts in the Rome System of Justice' (2008) 49 Harvard International Law Journal 53; Carsten Stahn, 'Complementarity: A Tale of Two Notions' (2008) 19 Criminal Law Forum 87; Olympia Bekou, 'A Case for Review of Article 88, ICC Statute: Strengthening a Forgotten Provision' (2009) 12 New Criminal Law Review 468; Morten Bergsmo, Olympia Bekou and Annika Jones, 'Complementarity After Kampala: Capacity Building and the ICC's Legal Tools' (2010) 2 Goettingen Journal of International Law 791; Olympia Bekou, 'Crimes at Crossroads: Incorporating International Crimes at the National Level' (2012) 10 Journal of International Criminal Justice 677; Justine Tillier, 'The ICC Prosecutor and Positive Complementarity: Strengthening the Rule of Law?' (2013) 13 International Criminal Law Review 507; Geoff Dancy and Florencia Montal, 'Unintended Positive Complementarity: Why International Criminal Court Investigations May Increase Domestic Human Rights Prosecutions’ (2017) 111 American Journal of International Law 35.

52 Rowland JV Cole, 'Africa's Relationship with the International Criminal Court: More Political than Legal' 14 Melbourne Journal of International Law 1, 29.

53 Adam Branch, 'Uganda's Civil War and the Politics of ICC Intervention' (2007) 21 Ethics \& International Affairs 179, 194

54 Payam Akhavan, 'The Lord's Resistance Army Case: Uganda's Submission of the First State Referral to the International Criminal Court' (2005) 99 American Journal of International Law 403, 404. 
ordu tarafından toplu şekilde öldürme, köleleştirme, işkence, tecavüz ve çocukların zorla askere alınması gibi suçların işlendiği ve bu suçların da Roma Statüsü Madde 7 "insanlığa karşı işlenen suçlar" kapsamında değerlendirilebileceği açıktır. ${ }^{55}$ Temel hukuki problem ise hem dava yürütmeye istekli hem de donanımlı olan bir taraf devletin Uluslararası Ceza Mahkemesi'ne yaptığı başvuruyu, mahkemenin kendi kurucu sözleşmesini ihlal ederek kabul etmesidir. Savcının davayı kabul etme kararı, Roma Statüsünün temel prensiplerinden olan tamamlayıc1lı prensibini zedeler niteliktedir.

Hem Uganda davası hem de diğer devletlerin mahkemeye kendilerinin başvurduğu (self-referral) davalar (Kongo Demokratik Cumhuriyeti ve Orta Afrika Cumhuriyeti gibi), hukuki olarak devletlerin böyle bir yetkilerinin Roma Statüsünde bulunup bulunmadığına dair literatürde bir tartışmaya yol açmıştır. Roma Statüsü Madde 14, bir taraf devletin mahkemeye başvuruda bulunma hakkını şu şekilde düzenlemiştir:

Madde 14

1. Bir taraf devlet, Mahkeme Savcısına, Mahkemenin yargı yetkisi alanına giren bir veya birden fazla suçun işlenmiş göründüğunü bildirip, bu suçlarla ilgili bir ya da daha fazla belirlenmiş kişinin yargılanıp yargılanmayacağı hususunun belirlenmesi amacıyla durumun soruşturulmasını Savcıdan talep edebilir.

2. Bir başvuru, mümkün olduğu kadar ilgili yönleri ortaya koymalı ve başvuran devletin elindeki belgelerle desteklenmelidir.

Statünün hazırlanması aşamalarında (travaux préparatoires), bu maddenin, devletlerin kendilerini bizzat kendilerinin mahkemeye getirmelerini (self-referral) kapsayacak şekilde düşünülmediği ve tasarlanmadığ 1 Schabas tarafından net bir şekilde ortaya konmuştur. ${ }^{56}$ Schabas, mahkemenin bu maddeyi, devletlerin kendilerini de dava edebilecekleri şeklinde yorumlamasını, "yorumlama yoluyla saptırma (interpretative deviations)" olarak tanımlamıştır. ${ }^{57}$ Devletlerin kendilerini mahkemeye getirme yetkilerinin Statü tarafından tanınıp tanınmadığı hususu literatürde tartışılan ve üzerinde anlaşmaya varılamamış bir mevzudur. ${ }^{58}$ Bununla birlikte, Russell Buchan'in haklı olarak belirttiği gibi, akademik tartışma her ne kadar devam etse de, Uluslararası Ceza Mahkemesi'nin bu mekanizmayı, Uganda, Kongo Demokratik Cumhuriyeti ve Orta Afrika Cumhuriyeti örneklerinde olduğu gibi, belirsizliğe yer burakmayacak şekilde kabul ettiği kesindir..$^{59}$

55 ibid.

56 Schabas (n 22) 760

57 ibid.

58 Mahnousk H Arsanjani and W Michael Reisman, 'The Law-in-Action of the International Criminal Court' (2005) 99 American Journal of International Law 385; Payam Akhavan, 'Self-Referrals Before the International Criminal Court: Are States the Villains or the Victims of Atrocities?' (2010) 21 Criminal Law Forum 103; D Robinson, 'The Controversy over Territorial State Referrals and Reflections on ICL Discourse' (2011) 9 Journal of International Criminal Justice 355.

59 Russell Buchan, 'The Mavi Marmara Incident and the International Criminal Court' (2014) 25 Criminal Law Forum 465 , 473. 
Dava ile ilgili diğer önemli problemlerden biri de Uganda Hükümetinin davayı Kuzey Uganda'daki çatışma ile sınırlayarak uluslararası suçların yalnızca Tanrı'nın Direniş Ordusu tarafından işlenen kısmına bakılması arzusunda olmasıdır. Uganda Savunma Bakanı, Uganda Parlamentosunda yaptığı bilgilendirmede Uluslararası Ceza Mahkemesi'nin Kuzey Uganda'daki Tanrı'nın Direniş Ordusu mensubu "teröristleri" kovuşturacağını belirtmekte ve Uluslararası Ceza Mahkemesi'nde yargılanacak kişi sayısının ise beş kişiyi aşmayacağını taahhüt etmektedir. ${ }^{60}$ Buna ek olarak Savcının Uganda Cumhurbaşkanı ile birlikte medyada görünmesi de mahkemenin tarafsızlığına olan inancı derinden sarsmıştır. ${ }^{61}$ Uganda Hükümetinin, Uluslararası Ceza Mahkemesi’ni “düşmanını yenmek için bir araç” olarak kullanma ve böylelikle çatışmayı kendi lehine şekillendirme isteğinde olduğu açıktır. ${ }^{62}$ Hukuki açıdan problem yaratan durum ise Savcının, mahkemenin bu şekilde kullanılmasını kabul etmesi ve yarg1 yetkisini kullandığı davalarda rejim kuvvetlerinin işlediği suçları yok sayarak sadece isyancı (rebel) kuvvetlerin işlediği suçları soruşturmaya rıza göstermesidir. ${ }^{63}$

Uluslararası Ceza Mahkemesi'nin bu davayı kabul etmesi ise mahkemenin kendisinin sahada politik çıkarlar için araçsallaştırılmasına (instrumentalization) göz yumması ve meşruiyetini tehlikeye atması olarak yorumlanmış ve de kabul edilebilirlik değerlendirmesi sırasında Uganda'nın kapasitesinin dikkate alınmaması, Madde 17 'nin ihlali olarak değerlendirilmiştir. ${ }^{64}$ Branch'a göre, dava sırasında, Uganda'nın işler vaziyetteki (functioning) yargı sistemi Tanrı'nın Direniş Ordusu generallerini kovuşturmak için yetersiz değildi. ${ }^{65}$ Uganda'nın Uluslararası Ceza Mahkemesi'ni olaya müdahil ederek yapmak istediği o sırada gündemde olan barış görüşmelerini ve Genel Af Yasasını (the Amnesty Act) geçersiz kılmaktı. ${ }^{66}$ Dolayısıyla mahkeme stratejik bir amaçla taraf devlet tarafından olaylara müdahil edildi. ${ }^{67}$ "Politikleşmiş adalet" olarak tanımlanan bu durum, taraf devletlerin kendi politik çıkarları için veya kendi düşmanlarını cezalandırmak için Uluslararası Ceza Mahkemesi’ni kullandığı koşulları işaret eder. ${ }^{68}$ Özellikle iç savaşın yaşandığı devletlerde, devletlerin kendi ülkelerinde bir soruşturma yürütülmesini istemesi çoğu zaman düşman tarafin

60 Sarah MH Nouwen and WG Werner, 'Doing Justice to the Political: The International Criminal Court in Uganda and Sudan' (2010) 21 European Journal of International Law 941, 950.

61 Michael Otim and Marieke Wierda, 'Justice at Juba: International Obligations and Local Demands in Northern Uganda' in Nicholas Waddell and Phil Clark (eds), Courting Conflict? Justice, Peace and the ICC in Africa (Royal African Society 2008) 22.

62 Nouwen and Werner (n 60) 949.

63 Jean-Baptiste Jeangène Vilmer, 'The African Union and the International Criminal Court: Counteracting the Crisis' (2016) 92 International Affairs 1319, 1331.

64 Branch (n 53) 179.

65 ibid 187

66 ibid.

${ }_{67}$ Valerie Freeland, 'Rebranding the State: Uganda's Strategic Use of the International Criminal Court: Rebranding the State: Uganda and the ICC' (2015) 46 Development and Change 293.

68 Steven C Roach, 'Legitimising Negotiated Justice: The International Criminal Court and Flexible Governance' (2013) 17 The International Journal of Human Rights 619, 625. 
işlediği iddia edilen suçların uluslararası kamuoyuna duyurulması amacını taşır. ${ }^{69}$ $\mathrm{Bu}$ devletler, Uluslararası Ceza Mahkemesi'nin duruma müdahil olmasının, ülke içindeki siyasi ve askeri amaçlarına erişimi kolaylaştırmasını umarlar. ${ }^{70}$

Uluslararası Ceza Mahkemesi'nin bu ve buna benzer koşullarda Madde 17'deki şartları gözetmeksizin davaları açmaktaki aşırı istekliliği ortadadır. Her ne kadar Afrika'daki devletlerin altyapı ve teknik imkanlar bakımından zayıf olması nedeniyle davaların bu bölgede kümelendiği yönünde açıklamalar yapılsa da, bu açılamaların inandırıcılığı yoktur. Uluslararası Ceza Mahkemesi Savcısının dava seçiminde başvurduğu Madde 17'de muğlaklık olduğu ve bu muğlaklığın Savcıya geniş bir takdir yetkisi tanıdığı açıktır. Ancak, Savcının kriterleri uygulamada kendisine verilen takdir yetkisini kullanımı problemler yaratmaktadır. Davaların belli bölgelerde kümelenmesi, istekli ve yeterli kapasitesi olan devletlerin dahi başvurularının kabul edilmesi, Roma Statüsünün temel prensiplerinden olan tamamlayıcılık ilkesinin göz ardı edilmesi, seçilen davalarda sadece bir tarafın işlediği suçların kovuşturulması ve dolayısıyla mahkemenin iç politika amaçları için kullanılması, Savcının kendisine verilen takdir yetkisini problemli bir şekilde kullandığını göstermektedir. Uluslararası Ceza Mahkemesi'nin meşruiyet krizi yaşamasında ve politikleşmekle suçlanmasında Savcının kararlarının ve seçimlerinin de rolü olduğu kesindir. Bir sonraki bölümde, Savcının başvurduğu kabul edilebilirlik şartlarından olan vahamet kriteri (gravity threshold) incelenecek ve bu kriterdeki belirsizliğin uygulamaya yansımasındaki problemler tartışlacaktır.

\section{Vahamet Şartının Uluslararası Ceza Mahkemesi Savcısı Tarafından Kullanımında Ortaya Çıkan Problemler}

Davaların kabul edilebilirlik değerlendirmesinin merkezinde isteksizlik (unwillingness) ve yetersizlik (inability) kriterlerine ek olarak, vahamet (gravity) kriteri yatmaktadır. Uluslararası Ceza Mahkemesi Savcısının dava seçiminde önyargılı ve yanlı olduğuna ve mahkemenin seçici adalet (selective justice) uyguladığına yönelik eleştirilere, Savcılık Makamı (the Office of the Prosecutor) vahamet şartını cevap olarak ileri sürmüştür..$^{71}$ Roma Statüsü Madde 17(1)(d)'ye göre, "[d]ava konusunun, Mahkeme tarafindan başkaca işlem gerektirecek derecede vahim bulunmaması halinde" söz konusu olay mahkeme tarafından kabul edilemez bulunacaktır. ${ }^{72}$ Savcının bir olayın vahim olup olmadığına nasıl karar vereceği Madde 17(1)(d)'de net olarak belirtilmemiştir. Zaten ağır insan hakları ihlallerini soruşturma

69 Paola Gaeta, 'Is the Practice of "Self-Referrals" a Sound Start for the ICC?' (2004) 2 Journal of International Criminal Justice 949, 951.

70 ibid.

71 Uluslararası Ceza Mahkemesi, 'Understanding the International Criminal Court', <https://www.icc-cpi.int/iccdocs/PIDS/ publications/UICCEng.pdf> Erişim Tarihi 14 Aralık 2020.

72 Uluslararası Ceza Mahkemesi Roma Statüsü (n 31). 
yetkisine sahip olan Uluslararası Ceza Mahkemesi'nin bu ihlaller arasından vahim olanlarını ayırt etmesi, kabul etmek gerekir ki, kolay bir görev değildir. ${ }^{73}$

Uluslararası Ceza Mahkemesi eski Savcısı Luis Moreno-Ocampo olay seçiminde hangi unsurlara dikkat ettiğine açıklık getirmeyi amaçladığg ve daha sonradan makale haline getirilen konuşmasında, "vahametin olay ve dava seçiminde en önemli meselelerden biri” olduğunu belirtmiştir. ${ }^{74}$ Ele aldığı ilk üç olayın (Uganda, Kongo Demokratik Cumhuriyeti ve Darfur, Sudan) "tam da vahamet kriteri nedeniyle inceleme altında" olduğunu belirten Moreno-Ocampo, bunun yanı sira vahamete dayalı bir değerlendirmenin kolay olmadığını da eklemektedir. ${ }^{75}$

Savcının soruşturma başlatma aşamasında dikkate alması gereken vahamet kriteri Roma Statüsü Madde 53(1)'de ele alınmıştır. ${ }^{76}$ Fakat bu madde, vahamet kriterinin değerlendirilmesinde ne tür faktörlerin ele alınması gerektiğine dair yeterli bilgi sunmamaktadır. Bu durum ise, Uluslararası Ceza Mahkemesi Savcısına karar verme aşamasında geniş bir takdir yetkisi tanımaktadır. ${ }^{77}$ Davaların kabul edilebilirliği aşamasında Savcıya geniş yetki verilmesinin nedeni aslına bakılırsa Uluslararası Ceza Mahkemesi’nin bağımsızlığının sağlanmasıydı. Bağımsız ve tarafsız bir Savcının dava seçimine dair tüm yetkileri elinde tutması, Roma Statüsünün görüşüldüğü aşamalarda, mahkemeyi hem Birleşmiş Milletler Güvenlik Konseyi’nin hem de güçlü devletlerin vesayetinden kurtarabilecek bir çözüm olarak düşünülmüştür. ${ }^{78}$ Bağımsız bir Savcının dava seçiminde tüm yetkileri elinde bulundurmasına karşı çıkan tarafların başında Amerika Birleşik Devletleri (ABD) gelmekteydi. ${ }^{79}$ ABD, politik olarak herhangi bir sorumluluk taşımayan (politically unaccountable) bir Savcının herhangi bir taraf devletin vatandaşlarını politik nedenlerden ötürü yargılayabileceğine dair endişelerini dile getirmiş ve mahkeme Savcısının, Birleşmiş Milletler Güvenlik Konseyi'ne karşı sorumlu olması gerektiği yönünde fikir öne sürmüştür. ${ }^{80}$ Fakat, görüşmeler sırasında tarafsız bir mahkemenin ancak ve ancak politik kurumlardan bağımsız hareket eden ve kabul edilebilirlik aşamasında hangi suçların vahim olup olmadığına bizzat karar veren bir Savcı ile ortaya çıkabileceği fikri çoğunluk tarafından kabul görmüştür.

73 Chandra Lekha Sriram and Stephen Brown, 'Kenya in the Shadow of the ICC: Complementarity, Gravity and Impact' (2012) 12 International Criminal Law Review 219, 235.

74 Luis Moreno-Ocampo, 'Keynote Address: Integrating the Work of the ICC into Local Justice Initiatives' (2006) 21 American University International Law Review 497, 498.

75 ibid.

76 Uluslararası Ceza Mahkemesi Roma Statüsü (n 31).

77 Alette Smeulers, Maartje Weerdesteijn and Barbora Hola, 'The Selection of Situations by the ICC: An Empirically Based Evaluation of the OTP's Performance' (2015) 15 International Criminal Law Review 1, 6.

78 Tiemessen (n 10) 448.

79 Amerika Birleşik Devletleri’nin Uluslararası Ceza Mahkemesi’ne yönelik eleştirileri için, bakınız: John R Bolton, 'The Risks and Weaknesses of the International Criminal Court from America's Perspective' (2001) 64 Law and Contemporary Problems 167.

80 Sten Verhoeven, Jan Wouters and Bruno Demeyere, 'The International Criminal Court's Office of the Prosecutor: Navigating between Independence and Accountability?' (2008) 8 International Criminal Law Review 273, 279. 
Savc1lık Makamı2003 Haziran-2006Haziranarasında mahkemenin gerçekleştirdiği aktiviteleri değerlendirdiği 2006 yılında yayınlanan raporda, vahamet kriterini değerlendirirken şu faktörlere dikkat ettiğini açıklamıştır: suçların derecesi (the scale of the crimes); suçların doğası (the nature of the crimes); suçların işleniş biçimi (the manner of commission of the crimes); ve suçların etkisi (the impact of the crimes). ${ }^{81}$ Benzer bir şekilde, Savcılık Makamı 2007 yılında yayınlamış olduğu "Adaletin Tecellisi üzerine Rapor" başlıklı raporunda adaletin tecellisi için dikkate alınan aşikar (explicit) faktörler bölümünde suçların vahametinin nasıl ve ne şekilde uygulandığını açıklarken, mahkemenin yetki alanına düşen her suçun kabul edilebilirlik için yeterli şartı taşımadığını, bu suçların ayrıca Madde 17(1)(d)'de belirtilen vahamet kriterini de sağlamaları gerektiğinin altını çizer. ${ }^{82}$ Vahamet kriterinin değerlendirilmesinde tam olarak hangi faktörlere dikkat edildiğini ise 2006 y1lındaki raporla uyumlu bir biçimde açıklamaktadır: suçların derecesi, suçların doğası, suçların işleniş biçimi ve etkisi mahkemenin vahamet kriteri değerlendirmesinde dikkate alınan faktörler olarak belirtilmiştir. ${ }^{83}$ Derece (scale), doğa (nature), işleniş biçimi (manner) ve etki (impact) terimlerinin hukuki olarak ne anlam ifade ettikleri ise Savcılık tarafindan bu raporda net bir şekilde açıklanmamıştır. Belirtilen terimler, Nisan 2009'da Uluslararası Ceza Mahkemesi’nin yayınladığı "Savcının Hizmet Düzenlemeleri”" (Regulations of the Office of the Prosecutor) adlı raporda Düzenleme 29 başlığ altında yer almışlardır. ${ }^{84}$ Savcı, bu dört faktörün dikkate alındığ 1 bir vahamet testi sonucunda, Kongo Demokratik Cumhuriyeti'ndeki ve Kuzey Uganda'daki olayların mahkemenin yarg1 yetkisi kapsamında "kabul edilebilirliği en vahim olayları" (the gravest admissible situations) oluşturdukları sonucuna vardığını ifade etmiştir. ${ }^{85}$ Buna ek olarak, Birleşmiş Milletler Güvenlik Konseyi tarafindan mahkemeye sunulan Darfur, Sudan'daki olayların da yine "çok net bir şekilde" vahamet kriterini sağladığ 1 ifade edilmiştir. ${ }^{86}$

Savcı, bu raporda, vahamet kriterini sağlamayan olaylar hakkında da açıklamalar yapmıştır. Örneğin, Venezuela' daki olayların mahkemenin yargı yetkisi kapsamında değerlendirilmesi için makul bir temelin ortada olmadığını ortaya koymuş, Irak’ta yaşanan olaylarda ise "çok sınırlı sayıda ölümler ve insanlık dışı muameleler olduğu"

\footnotetext{
1 Uluslararası Ceza Mahkemesi Savcılık Makamı, 'Report on the Activities Performed During the First Three Years (June 2003 - June 2006)' (n 50) 6.

82 Uluslararası Ceza Mahkemesi Savc1lik Makam1, 'Policy Paper on the Interests of Justice' (Eylül 2007) <https://www. icc-cpi.int/nr/rdonlyres/772c95c9-f54d-4321-bf09-73422bb23528/143640/iccotpinterestsofjustice.pdf > Erişim Tarihi 14 Aralık 2020.

83 ibid.

${ }^{84}$ Uluslararas1 Ceza Mahkemesi, 'Regulations of the Office of the Prosecutor' (Nisan 2009) < https://www.icc-cpi.int/nr/ rdonlyres/fff97111-ecd6-40b5-9cda-792bcbe1e695/280253/iccbd050109eng.pdf> Düzenleme 29, Erişim Tarihi 14 Aralık 2020.

85 Uluslararası Ceza Mahkemesi Savcılık Makamı, 'Report on the Activities Performed During the First Three Years (June 2003 - June 2006)' (n 50) 6.

86 ibid 7
} 
gerekçesiyle gerekli vahametin oluşmadığını ileri sürmüştür. ${ }^{87}$ Raporda, "vahamet karşılaştırması" da yapılmaktadır. Uganda soruşturması hakkında bilgi veren Savcı, kendisine Uganda Hükümeti tarafından yönlendirilen (self-referral) olaylarda, Uganda Hükümetini bağımsız bir șekilde sorușturmayı yürüteceğine dair bilgilendirdiğini ifade etmektedir. ${ }^{88}$ Sonrasında ise, Savc1 yaptığ 1 soruşturma sonucunda Kuzey Uganda'da Tanrı'nın Direniş Ordusu tarafından işlenen suçların bu bölgedeki “diğer grupların" işlediği suçlara kıyasla "daha vahim" olduğu sonucuna varmaktadır. ${ }^{89}$ Savc1, Uganda Hükümeti tarafından işlendiği iddia edilen suçların, Tanrı'nın Direniş Ordusu tarafından işlendiği iddia edilen suçlardan daha az vahim olmasını soruşturma açmama nedeni olarak sunmaktadır. Bu şekilde yapılan karşılaştırmaların ve değerlendirmelerin hem hukuki açıdan objektif kriterlere dayanmadığı hem de ilgili toplumlar nezdinde mahkemeye karşı bir güven oluşturmadığı açıktır.

Savcının "daha az vahim" yahut "daha çok vahim" değerlendirmeleri literatürde eleştirilmiştir. Savcının Roma Statüsünde öngörülen "yasal vahamet (legal gravity)" kriterini "göreceli vahamet (relative gravity)" ile karıştırdığı ve daha da kötüsü, dava kabul edilebilirlik incelemesi sırasında "göreceli vahamet"i, "yasal vahamet" ile ikame ettiği yönünde eleştiriler olmuştur. ${ }^{90} \mathrm{Bu}$ durumu Schabas da ağır bir şekilde eleştirmiştir. Schabas'a göre, Irak’ta İngiliz askeri birliklerince öldürülen insan sayısının Kongo Demokratik Cumhuriyeti'nde öldürülen binlerce insanla karşılaştırılması ve bunun üzerine Irak’ta yaşananların “yeterince vahim olmaması (not grave enough)" sonucu, Savcının ortaya koyduğu hatalı bir değerlendirmenin neticesidir. ${ }^{91}$ Vahamet değerlendirmesi karşılaştırmalar üzerinden değil, eldeki davanın kendi başına tüm boyutlarıyla incelenmesi ile gerçekleştirilmelidir. Karşılaştırmalar üzerinden yapılan bir vahamet testi, birbirinden ziyadesiyle farklı koşulların (context), olayların ve suçların birbiriyle karşılaştırılması ve karıştııılması ile sonuçlanarak yanlış değerlendirmelere yol açma riski içerir.

Ayrıca, "daha az vahim" olarak addedilen Uganda Hükümetinin işlediği suçlar üzerine mahkeme ile sivil toplum örgütleri arasında bir fikir birliği mevcut değildir. İnsan Hakları İzleme Örgütü, Uluslararası Ceza Mahkemesi Savcısının Uganda Hükümeti askerlerince işlenen suçları görmezden gelmemesi gerektiği yönünde fikir beyan etmiş̧tir. ${ }^{92}$ Örgüte göre, Uganda Hükümeti askerleri (Ugandan People's Defense Forces - UPDF) hukuk dış1 ölümlere neden olmuş, toplu tecavüzler geçekleştirmiş,

\footnotetext{
87 ibid 10.

88 ibid 14.

89 ibid.

90 Susana Sã and Katherine A Cleary, 'The Gravity Threshold of the International Criminal Court' (2008) 23 American Journal of International Law 807; Ignaz Stegmiller, 'The Gravity Threshold under the ICC Statute: Gravity Back and Forth in Lubanga and Ntaganda' (2009) 9 International Criminal Law Review 547.

91 Schabas (n 22) 741.

92 Human Rights Watch, 'ICC: Investigate All Sides in Uganda' (Şubat 2004) <https://www.hrw.org/news/2004/02/04/iccinvestigate-all-sides-uganda>. (yazarın çevirisi) Erişim Tarihi 14 Aralık 2020.
} 
bir milyondan fazla sivili zorla yerinden etmiş ve 15 yaş altı çocukları hükümet milis kuvvetlerine almıştır. ${ }^{93}$ Benzer şekilde Uluslararası AfÖrgütü de, mahkemenin inceleme altına aldığı suçlara Uganda Hükümeti askerleri (UPDF) tarafından işlenen suçların da dahil edilmesi gerektiğini savunmuştur. ${ }^{94}$ Tüm bu suçların savaş suçları veya insanlığa karşı suçlar kapsamına girmesi ve Uluslararası Ceza Mahkemesi'nin yetki alanında bulunması nedeniyle Uganda Hükümetinin de mahkeme tarafından soruşturulması gerekmektedir. ${ }^{95}$ Ancak, Savcı yayınladığı raporda bu suçları "daha az vahim” olarak nitelemiş ve soruşturma yürütmemeyi tercih etmiştir. Roma Statüsündeki vahamete ilişkin maddelerdeki (Madde 17(1)(d) ve Madde 53(1)(c)) muğlaklık ve bunun sonucu olarak da Savcıya tanınan geniş takdir yetkisinin uygulamaya yansımaları, mahkemenin temel prensipleri olan tamamlayıcılık ve mahkemenin tarafsızlığg ilkelerini zedelemekte ve mahkemenin meşruiyetini zayıflatmaktadır.

Savcılık 2013 yılında yayınladığı raporla vahamet testinde dikkate alınan suçun derecesi, (scale), suçun doğası (nature), suçun işleniş biçimi (manner) ve suçun etkisi (impact) terimlerinin hukuki olarak ne anlam ifade ettiğini şu şekilde açıklayarak değerlendirme aşamasına şeffaflık getirmeyi amaçlamıştır:

(a) Suçun derecesi, suçtan doğrudan ve dolaylı etkilenen mağdurların sayısı, suçtan doğan zararın kapsamı, özellikle mağdurların ve ailelerinin uğradığı fiziksel veya psikolojik zarar, veya suçların coğrafi veya zamansal yayılımı üzerinden değerlendirilir. ${ }^{96}$

(b) Suçların doğası, her bir suçun spesifik unsurlarına örneğin öldürme, tecavüz ve cinsel şiddeti içeren diğer suçlara ve çocuklara karşı işlenen suçlara, işkenceye (persecution), veya bir grubun yok olmasına yol açacak koşulların yaratılmasına işaret eder. ${ }^{97}$

(c) Suçların işleniş biçiminde, suçun işlenişinde kullanılan yöntemlere, failin niyetine ve iştirak derecesine, suçların ne dereceye kadar sistematik olduğuna ya da bir plandan mı yahut organize edilmiş bir politikadan (policy) mı doğduğuna, yoksa gücün kötüye kullanımından veya resmi yetkiden mi doğduğuna, gaddarlık (cruelty) unsurları olup olmadığına, mağdurların güçsüzlüğüne (vulnerability), ve ayrımcıllğı içeren herhangi bir güdünün, veya grubun yok edilmesi için kullanılan tecavüz ve cinsel şiddetin olup olmadığına bakılır. ${ }^{98}$

(d) Suçların etkisi, mağdurların çektikleri güçlükler (sufferings) ve artan güçsüzlükleri; aşılanan (instilled) korku, veya söz konusu toplulukların maruz bırakıldığı sosyal, ekonomik, ve çevresel zarar üzerinden değerlendirilir. ${ }^{99}$

93 ibid

94 Amnesty International, 'Uganda: First Ever Arrest Warrants by International Criminal Court - A First Step Towards Addressing Impunity' (Ekim 2005) <https:/www.amnesty.org/download/Documents/80000/afr590082005en.pdf> (yazarın çevirisi) Erişim Tarihi 14 Aralık 2020.

95 Kasaija Phillip Apuuli, 'The International Criminal Court (ICC) and the Lord's Resistance Army (LRA) Insurgency in Northern Uganda’ (2004) 15 Criminal Law Forum 391, 405.

96 Uluslararası Ceza Mahkemesi Savcılık Makamı, 'Policy Paper on Preliminary Examinations' (Kasım 2013) < https://www. icc-cpi.int/iccdocs/otp/otp-policy_paper_preliminary_examinations_2013-eng.pdf> paragraf 62 (yazarın çevirisi) Erişim Tarihi 14 Aralık 2020.

97 ibid paragraf 63 (yazarın çevirisi)

98 ibid paragraf 64 (yazarın çevirisi)

99 ibid paragraf 64 (yazarın çevirisi) 
Görüldüğü üzere, bu raporla Savcılık, Uluslararası Ceza Mahkemesi’ne kabul edilebilirlik şartlarına şeffaflık sağlamayı ve dolayısıyla mahkemenin meşruiyetini güçlendirmeyi amaçlamıştır. $\mathrm{Bu}$ faktörlerin uygulamada bir şeffaflık getirip getirmeyeceği ise ancak zamanla ortaya çıkacaktır.

Vahametin anlamı ve kapsamı Roma Statüsünde net bir şekilde ortaya konmadığı için, Uluslararası Ceza Mahkemesi'nin vahamet değerlendirmesi yaptığı kararların incelenmesi bu kavramı anlamaya yardımcı olabilir. Makalenin geri kalanında, vahametin kabul edilebilirlik değerlendirmesi aşamasında merkeze alındığ davalardan olan Kongo Demokratik Cumhuriyeti vatandaşları olan Lubanga ve Ntaganda'nın 2006 yılında gerçekleşen davaları incelenecektir. Bu inceleme ile vahametin Uluslararası Ceza Mahkemesi Savc1 ve Hakimleri tarafindan nasıl değerlendirildiğinin somut bir örnek üzerinden netleştirilmesi amaçlanmaktadır. Vahamet değerlendirilmesinin hem olay hem de dava aşamasında ele alındığı farklı davalar da olmakla birlikte, Lubanga ve Ntaganda davaları mahkemenin vahamet kavramının çerçevesini çizerken kendi içinde de ortaya çıkan anlayış farklılıklarını göstermesi açısından bu makale için önem arz etmektedir.

Lubanga ve Ntaganda davalarında Uluslararası Ceza Mahkemesi'nin Ön-Yargılama Mahkemesi (Pre-Trial Chamber), Savcının vahim olarak değerlendirdiği bu iki olayı bir de kendisi vahamet testinden geçirmiştir. Ön-Yargılama Mahkemesi tutuklama ve celpname çıkarmak, ve ayrıca soruşturma aşamasında kişilerin hak ve özgürlüklerini güvence altına almakla yükümlüdür. Bu mahkemeye göre vahamet değerlendirilmesi iki aşamada yapılmalıdır: olayın soruşturulmasına başlama aşamasında ve dava aşamasında. ${ }^{100} \mathrm{Bu}$ mahkemeye göre vahamet değerlendirilmesi yapılırken şu 3 husus dikkate alınmalıdır:

1) Dava konusu davranışlar sistematik veya büyük ölçekli olmalıdırlar. Suç oluşturan münferit olaylar herhangi bir vahamet ortaya koymadığından, mahkemenin yargı yetkisi dışında kalırlar. ${ }^{101}$

2) Dava konusu davranışlar uluslararası kamuoyunda "sosyal bir alarm" durumu yaratmalıdırlar. Savcının olay seçiminde, kamuoyunda bir alarm durumunun olup olmadığı vahamet ile yakından ilişkili bir faktördür. ${ }^{102}$

3) Ön-Yargılama Mahkemesinin görüşüne göre, vahamet testi, Mahkemenin sadece, “işlenen suçlarda sorumluluğu en çok olan en yüksek kademedeki liderleri” yargılamasını gerektirmektedir. ${ }^{103}$ Mahkemenin yaptığı bu değerlendirme sonucunda Ntaganda'nin en yüksek kademedeki yetkililerden biri olmadığı için serbest bırakılması önerilmektedir.

\footnotetext{
100 Uluslararası Ceza Mahkemesi, ‘Kongo Demokratik Cumhuriyeti Olayı’ Ön-Yargılama Mahkemesi Kararı, No: ICC-01/0401/07 (Şubat 2006) https://www.icc-cpi.int/RelatedRecords/CR2008_04184.PDF paragraf 45, Erişim Tarihi 14 Aralık 2020.

101 ibid paragraf 47.

102 ibid paragraf 47.

103 ibid paragraf 51.
} 
Ön-Yargılama Mahkemesinin ortaya koyduğu bu kriterler, Uluslararası Ceza Mahkemesi'nin dayandığı Roma Statüsünde veya Statünün hazırlanması aşamasında devlet temsilcilerinin ortaya koyduğu çalışmalarda (travaux préparatoires) kesinlikle yer almamaktadır. Mahkeme tamamen inisiyatif kullanarak vahametin kendisi tarafından nasıl anlaşıldığına ve kamuoyu tarafından da nasıl anlaşılması gerektiğine yönelik bir rehber hazırlama çabasına girişmiştir. Fakat Ön-Yargılama Mahkemesinin bu değerlendirmesi her ne kadar tamamlayıcılık ilkesi ile uyumlu bir şekilde taraf devletlerin yargılamalardaki rolünü artırma potansiyeline haiz olsa da, bu kriterlerin en yüksek kademede yer almayan yetkililerin işlediği suçların cezasız kalmasına (impunity) sebep olma ihtimali vardır. ${ }^{104}$ Nitekim, vahametin bu şekilde değerlendirilmesi ve tanımlanması Uluslararası Ceza Mahkemesi Temyiz Mahkemesi (Appeals Chamber) tarafindan reddedilmiştir.

Temyiz Mahkemesi, üç faktörü de derinlemesine incelemiş ve faktörlerin tümünü vahametin yorumlanmasında Ön-Yargılama Mahkemesinin yaptı̆̆ hatalar olarak değerlendirmiştir. Temyiz Mahkemesi, kararında, bu üç faktörü birer birer açıklayarak reddetmiştir. Öncelikli olarak, Temyiz Mahkemesine göre dava konusu davranışların sistematik ve büyük ölçekte olması Ön-Yargılama Mahkemesinin Roma Statüsüne aykırı şekilde ortaya koyduğu bir yorumlamadır. Roma Statüsü Madde 8(1)'e göre:

\section{Madde 8}

1. Bir plan veya politikanın ya da bu tarz suçların büyük çapta işlenmesinin bir parçası olarak işlenmesi başta olmak üzere, Mahkemenin savaş suçları üzerinde yargı yetkisi vardır. ${ }^{105}$

Temyiz Mahkemesi, bu maddede yer alan "başta olmak üzere (in particular when)" ifadesinin Ön-Yargılama Mahkemesi tarafindan yanlış ve dar bir kapsamda yorumlandığına dikkat çeker. ${ }^{106}$ Statü, bir plan yahut politika dahilinde veya geniş çaptaki sistematik ve büyük ölçekteki suçlar başta olmak üzere diyerek, bu suçlar dışındaki suçların da mahkemenin yargı yetkisine dahil olabileceğini ortaya koymaktadır. Dolayısıyla Temyiz Mahkemesi, alt mahkemenin Statüde yer almayan "sistematik" kelimesini kullanarak, olması gerekenden daha yüksek bir eşik belirlediğini ileri sürer. ${ }^{107}$ Dolayısıyla Ön-Yargılama mahkemesinin Roma Statüsüne aykırı ve Uluslararası Ceza Mahkemesi'nin yetkisini kısıtlayıcı yönde bir vahamet değerlendirmesi yaptığı sonucuna ulaşılmıştır.

\footnotetext{
104 Linda M Keller, 'The Practice of the International Criminal Court: Comments on the Complementarity Conundrum' (2010) 8 Santa Clara Journal of International Law 199, 215.

105 Uluslararası Ceza Mahkemesi Roma Statüsü (n 31).

106 Uluslararası Ceza Mahkemesi, ‘Kongo Demokratik Cumhuriyeti Olayı’ Temyiz Mahkemesi Kararı, No: ICC-01/04 (Ocak 2011) <https://www.icc-cpi.int/CourtRecords/CR2011_01426.PDF> paragraf 46, Erişim Tarihi 14 Aralık 2020.

107 ibid.
} 
Alt mahkemenin vahamet değerlendirmesinde dikkate aldığ ikinci kriter olan sosyal alarm kriterini de Temyiz Mahkemesi reddetmiştir. Temyiz Mahkemesi, dava konusu davranışların uluslararası kamuoyunda "sosyal bir alarm" yaratması gerekliliğini sübjektif bir durum olarak değerlendirmiştir. ${ }^{108}$ Mahkemeye göre, bir olaya karşı uluslararası kamuoyunun tepki gösterip göstermemesi, bu durumun vahim olup olmadığını belirlemez. ${ }^{109}$ Nitekim, "uluslararası kamuoyu" gibi tanımı muğlak olan bir topluluğun tepkisinin Uluslararası Ceza Mahkemesi'nin kabul edilebilirlik değerlendirmesinde yer almaması yerinde bir karardır. Aynı şekilde, "sosyal alarm" ifadesi de yine sübjektif ve tanımı muğlak bir ifadedir. Bir olayın kim için sosyal bir alarm durumu teşkil ettiği, kim için teşkil etmediği çoğu zaman politik saikler doğrultusunda belirlenmektedir. Bu nedenle, mahkemenin bu şekilde bir ifadeyi kabul edilebilirlik değerlendirmesine dahil etmesi mahkemenin politikleşmesine yönelik eleştirileri güçlendirecek bir sonuca yol açabilirdi.

Üçüncü olarak, Ön-Yargılama Mahkemesi, Savcının bir olay veya dava üzerine kabul edilebilirlik değerlendirmesi yaptı̆̆ 1 aşamada, mahkeme önüne getirilen suçluların "en üst düzey yetkililer" olması şartını araması gerektiğini belirtmiş̧ir. Ancak bu durum Roma Statüsünde yer alan bir şart olmadığından bu kriter de Temyiz Mahkemesi tarafından Roma Statüsüne aykırı olduğu gerekçesiyle reddedilmiş̧ir. Roma Statüsü Giriş bölümü Paragraf 4 'te belirtildiği üzere, "çok ciddi suçların cezasız kalmaması ve ulusal düzeyde ve uluslararası iş birliğinin güçlendirilmesi suretiyle, bu suçların etkin bir şekilde kovuşturulmasının, güvence altına alınması" amaciyla Mahkeme kurulmuştur. ${ }^{110}$

Maddede belirtildiği üzere, Uluslararası Ceza Mahkemesi "çok ciddi suçları (most serious crimes)" kovuşturmak amacıyla kurulmuştur. Bu ciddi suçların kovuşturulması için bu suçların en üst kademedeki kişiler tarafından işlenmesi zorunluluğu yoktur. Dolayısıyla ciddi suçların üst kademelerde olmayan yetkililer tarafindan işlenmesi, bu suçların cezasız kalmasını, Roma Statüsüne göre, gerektirmez. Temyiz Mahkemesi, ciddi bir suçu orta kademedeki bir yetkilinin işlemesi durumunda, alt mahkemenin bu kriterinin "yıkıcı (devastating) sonuçlara yol açabileceğinin" altını çizer. ${ }^{111} \mathrm{Bu}$ durum, suçu işleyen kişinin "en yüksek yetkili" olmaması halinde mahkemenin yargı yetkisini kullanamamasına yol açar. Temyiz Mahkemesine göre, bu faktör, Uluslararası Ceza Mahkemesi'ni Roma Statüsüne aykırı bir biçimde "ancak aşırı sınırlı şekilde tanımlanmış bir kategorideki insanları" yargılayabilecek duruma sokmaktadır. ${ }^{112}$ Dolayısıyla, mahkemenin uluslararası suçları soruşturma ve kovuşturma kapasitesini kurucu sözleşmesine aykırı biçimde sınırlayan bu faktörün

\footnotetext{
108 ibid paragraf 49.

109 ibid.

110 Uluslararası Ceza Mahkemesi Roma Statüsü (n 31).

111 Uluslararası Ceza Mahkemesi, ‘Kongo Demokratik Cumhuriyeti Olayı’ Temyiz Mahkemesi Kararı (n 106) paragraf 36.

112 ibid.
} 
Temyiz Mahkemesi tarafından reddi yerinde bir karardır. Aksi yöndeki bir karar, mahkemenin caydırıcı (deterrent) rolüne zarar verebilirdi. ${ }^{113}$

Lubanga ve Ntaganda davaları akademik literatürde de ziyadesiyle tartışılmıştır. Ön-Yargılama Mahkemesinin, Roma Statüsünün dışına çıkarak Uluslararası Ceza Mahkemesi'nin vahamet değerlendirmesindeki yetkisini kısıtlayıcı ve daraltıcı bir yorumlama yoluna gitmesi eleştirilere yol açmıştır. ${ }^{114}$ Aşağ 1 ve orta kademelerdeki yetkililerin işledikleri suçların da mahkemenin yargı yetkisi kapsamında olması, Savcının yayınladığı (ve yukarıda da incelenen) raporlarla uyumlu olarak görülmüş ve Ön-Yargılama Mahkemesinin kararının Savcının raporlarıyla çelişkili olduğu ortaya konmuştur. ${ }^{15}$ Literatürde Temyiz Mahkemesinin kararı genel olarak kabul görse de, bu kararın tek eksik yönü vahamet testinde nelerin dikkate alınması gerektiği mevzusunda Temyiz Mahkemesinin sessizliği olmuştur. ${ }^{116}$ Temyiz Mahkemesi anlamı ve içeriği muğlak olan bu kavramı netleştirmek adına bir adım atmamış ve kavramın nasıl şekillendirilip nasıl somutlaştırılacağını yine Savcının inisiyatifine bırakmıştır. Bununla birlikte, incelenen dava örneği göstermektedir ki vahametin nasıl değerlendirileceği Uluslararası Ceza Mahkemesi tarafından da üzerinde uzlaşılan bir konu değildir. Mahkemenin farklı birimleri farklı faktörleri önermekte ve savunmakta iken, birimler arası anlayış farklı1ıkları net bir şekilde gözlemlenebilmektedir.

\section{Sonuç}

Uluslararası Ceza Mahkemesi'nin kurucu sözleşmesi olan Roma Statüsünde kabul edilebilirlik şartlarının muğlak bir şekilde düzenlendiği görülmektedir. Sözleşmelerin, özellikle de taraf devlet sayısı fazla olması amaçlanan sözleşmelerin, hazırlık aşamaları sırasında temel kavramların veya şartların muğlak bırakılması sık rastlanan bir durumdur. Bir sözleşmenin ortaya koyduğu amaçlara aykırı bir biçimde yorumlanması ve sözleşmenin tanıdığı yetkilerin politik saikler doğrultusunda kullanılması hem sözleşmenin hem de sözleşmenin uygulayıcılarının meşruiyetinin sarsılmasına neden olabilmektedir. Bu makale, Roma Statüsünü bu kapsamda değerlendirmiştir.

Makalede, Uluslararası Ceza Mahkemesi Savcısının, mahkemenin politikleştiği ve dolayısıyla meşruiyetini yitirdiği iddialarında oynadığı rolün altı çizilmiştir. Savcıya kabul edilebilirlik değerlendirmesi konusunda sözleşme tarafından geniş bir takdir yetkisi tanındığı kesindir. Ancak, makalede tartışıldığı üzere, tanınan takdir yetkisinin

113 Margaret M deGuzman, 'Choosing to Prosecute: Expressive Selection at the International Criminal Court' (2012) 33 Michigan Journal of International Law 265, 309.

114 Stegmiller (n 90) 552.

115 Mohamed M El Zeidy, 'The Gravity Threshold under the Statute of the International Criminal Court' (2008) 19 Criminal Law Forum 35, 49.

116 M O'Brien, 'Prosecutorial Discretion as an Obstacle to Prosecution of United Nations Peacekeepers by the International Criminal Court: The Big Fish/Small Fish Debate and the Gravity Threshold' (2012) 10 Journal of International Criminal Justice 525, 539 . 
uygulamada kullanılması problemler doğurmuştur. Makale, Savcının yetkisinde olan kabul edilebilirlik şartlarını iki ayrı bölümde ele almıştır. İlk olarak, Savcının Madde 17 'de belirtilmiş olan isteklilik ve yeterlilik üzerinden yaptığı değerlendirmeler incelenmiş ve bu değerlendirmelerin pratikte nasıl uygulandığı örnek olay ve davalar üzerinden gösterilmiştir. Savc1, örneğin, suçları kovuşturmaya hem istekli hem de donanımlı bir taraf devletin başvurusunu (self-referral) kabul ederek Roma Statüsünün temel prensiplerinden olan tamamlayıc1lık prensibine aykırı hareket etmiştir. Ayrıca Savcı, başvurusunu kabul ettiği devletlerde gerçekleşen çatışmaların sadece bir tarafına yönelik soruşturma ve kovuşturmalar yürütmektedir. Bu durum ise hem mahkemeyi devletlerin iç işlerinde ivme kazanmak için kullanılan bir araç haline dönüştürmekte hem de mahkemenin seçici, yanlı ve önyargılı bir şekilde hareket ettiği yönündeki iddiaları kuvvetlendirmektedir.

Makale, daha sonra Savcının takdir yetkisine bırakılmış olan vahamet testinin (Madde 17 ve Madde 53) ne anlama geldiğini ve pratikte Savcı tarafindan nasıl değerlendirildiğini incelemiştir. Roma Statüsünde vahamete ilişkin herhangi bir açıklama bulunmamaktadır. Dolayısıyla kendisine yönlendirilen olaylar arasından hangi olayın vahim olarak addedilebileceği tamamen Savcının inisiyatifindedir. Savcının vahamete ilişkin değerlendirmeleri de benzer şekilde mahkemenin politik saikler doğrultusunda hareket ettiği yönündeki eleştirileri güçlendirmiş ve derinleştirmiştir. Her ne kadar bu eleştirilere bir cevap olarak Savcılık vahamet değerlendirmesini şeffaflaştırmak amacıyla çeşitli raporlar yayınlamış olsa da, makalede tartışıldığı üzere bu raporlar ile vahametin tam anlamıyla netlik kazandığını söylemek henüz mümkün değildir. Makalenin ele aldığ 1 davalar göstermektedir ki Uluslararası Ceza Mahkemesi Savcısı, Ön-Yargılama Mahkemesi ve Temyiz Mahkemesi arasında da vahametin anlamına ve kapsamına yönelik büyük anlayış farklı1ıkları bulunmaktadır.

Uluslararas1 Ceza Mahkemesi Savcısının zor bir görevi olduğu kesindir. Dolayısıyla bu makale Savcının Roma Statüsü kapsamında kendisine verilen yetkileri kullanmakta yaşadığı güçlükleri kesinlikle göz ardı etmemektedir. Gerek başvuru sayısının fazla olması ve gerek mahkemenin kaynaklarının sınırlı olması, işlenen tüm uluslararası suçların Uluslararası Ceza Mahkemesi tarafından soruşturulmasını imkansız kılmaktadır. Bundan ötürü, Savcının Roma Statüsünün kendisine verdiği yetki kapsamında kabul edilebilirlik değerlendirmesine başvurarak mahkemeyi dava yükü nedeniyle işlemez duruma gelmekten kurtarması doğru ve yerinde bir uygulamadır. Bununla birlikte, Savcının olay ve dava seçiminde Roma Statüsünün ortaya koyduğu kriterleri uygulama ve değerlendirme yöntemlerinin, uluslararası kamuoyunda mahkemeye yönelik eleştirileri daha da derinleştirdiği de bir gerçektir. Roma Statüsündeki kabul edilebilirlik şartlarının Roma Statüsü prensiplerine uygun bir şekilde uygulanmadığı durumlar, Savcının seçici, yanlı ve önyargılı bir şekilde 
hareket ettiği iddialarını doğurmuştur. Mahkemenin politik saikler doğrultusunda hareket etmediğinin ispatı ve uluslararası kamuoyu nezdinde mahkemenin meşruiyetinin güçlendirilmesi için Savcının kendisine tanınan geniş takdir yetkisini daha objektif, şeffaf, tutarlı ve hakkaniyetli kullanması gerekmektedir.

Hakem Değerlendirmesi: Dış bağımsız.

Çıkar Çatışması: Yazar çıkar çatışması bildirmemiştir.

Finansal Destek: Yazar bu çalışma için finansal destek almadığını beyan etmiştir.

Peer-review: Externally peer-reviewed.

Conflict of Interest: The author has no conflict of interest to declare.

Grant Support: The author declared that this study has received no financial support. 


\section{Bibliyografya/Bibliography}

Ainley K, 'The International Criminal Court on Trial' (2011) 24 Cambridge Review of International Affairs 309.

Akhavan P, 'The Lord's Resistance Army Case: Uganda's Submission of the First State Referral to the International Criminal Court' (2005) 99 American Journal of International Law 403.

_ , 'Self-Referrals Before the International Criminal Court: Are States the Villains or the Victims of Atrocities?' (2010) 21 Criminal Law Forum 103.

Aksar Y, 'Uluslararası Ceza Mahkemesi ve Amerika Birleşik Devletleri (ABD)' (2003) 52 Ankara Üniversitesi Hukuk Fakültesi Dergisi 125.

Alibaba A, 'Uluslararası Ceza Mahkemesinin Kuruluşu' (2000) 49 Ankara Üniversitesi Hukuk Fakültesi Dergisi 181.

Amnesty International, 'Uganda: First Ever Arrest Warrants by International Criminal Court - A First Step Towards Addressing Impunity' (Ekim 2005) < https://www.amnesty.org/download/ Documents/80000/afr590082005en.pdfs

Apuuli KP, 'The International Criminal Court (ICC) and the Lord's Resistance Army (LRA) Insurgency in Northern Uganda' (2004) 15 Criminal Law Forum 391.

Arsanjani MH and Reisman WM, 'The Law-in-Action of the International Criminal Court' (2005) 99 American Journal of International Law 385.

Azarkan E, 'Uluslararası Ceza Mahkemesi ile Eski Yugoslavya Uluslararası Ceza Mahkemesinin Karşılaştırmalı Analizi’ (2004) 24 Milletlerarası Hukuk ve Milletlerarası Özel Hukuk Bülteni 211.

Bekou O, 'A Case for Review of Article 88, ICC Statute: Strengthening a Forgotten Provision' (2009) 12 New Criminal Law Review 468.

— , 'Crimes at Crossroads: Incorporating International Crimes at the National Level' (2012) 10 Journal of International Criminal Justice 677.

Bergsmo M, Bekou O and Jones A, 'Complementarity After Kampala: Capacity Building and the ICC's Legal Tools' (2010) 2 Goettingen Journal of International Law 791.

Bikundo E, 'The International Criminal Court and Africa: Exemplary Justice' (2012) 23 Law and Critique 21.

Bolton JR, 'The Risks and Weaknesses of the International Criminal Court from America's Perspective' (2001) 64 Law and Contemporary Problems 167.

Branch A, 'Uganda's Civil War and the Politics of ICC Intervention' (2007) 21 Ethics \& International Affairs 179.

Buchan R, 'The Mavi Marmara Incident and the International Criminal Court' (2014) 25 Criminal Law Forum 465.

Burke-White WW, 'Proactive Complementarity: The International Criminal Court and National Courts in the Rome System of Justice' (2008) 49 Harvard International Law Journal 53.

Burke-White WW, 'Implementing a Policy of Positive Complementarity in the Rome System of Justice' (2008) 19 Criminal Law Forum 59.

Cannon BJ, Pkalya DR and Maragia B, 'The International Criminal Court and Africa: Contextualizing the Anti-ICC Narrative' (2016) 2 African Journal of International Criminal Justice 6.

Cole RJV, 'Africa's Relationship with the International Criminal Court: More Political than Legal' 14 Melbourne Journal of International Law 1. 
Dancy G and others, 'What Determines Perceptions of Bias toward the International Criminal Court? Evidence from Kenya' (2020) 64 Journal of Conflict Resolution 1443.

Dancy G and Montal F, 'Unintended Positive Complementarity: Why International Criminal Court Investigations May Increase Domestic Human Rights Prosecutions’ (2017) 111 American Journal of International Law 35.

Danner AM, 'Enhancing the Legitimacy and Accountability of Prosecutorial Discretion at the International Criminal Court' (2003) 97 American Journal of International Law 510.

Davis C, 'Political Considerations in Prosecutorial Discretion at the International Criminal Court' (2015) 15 International Criminal Law Review 170.

deGuzman MM, 'Choosing to Prosecute: Expressive Selection at the International Criminal Court' (2012) 33 Michigan Journal of International Law 265.

Dugard J, 'Palestine and the International Criminal Court: Institutional Failure or Bias?' (2013) 11 Journal of International Criminal Justice 563.

Eberechi I, "Rounding Up the Usual Suspects": Exclusion, Selectivity, and Impunity in the Enforcement of International Criminal Justice and the African Union's Emerging Resistance' (2011) 4 African Journal of Legal Studies 51.

El Zeidy MM, 'The Gravity Threshold under the Statute of the International Criminal Court' (2008) 19 Criminal Law Forum 35.

Ezennia CN, 'The Modus Operandi of the International Criminal Court System: An Impartial or a Selective Justice Regime?' (2016) 16 International Criminal Law Review 448.

France 24, 'Sudan's Bashir Blasts ICC's "New Face of Colonialism"' (27 May 2013) <https://www. france24.com/en/20130527-african-union-icc-justice-sudan-bashir-kenya-kenyatta>

Freeland V, 'Rebranding the State: Uganda's Strategic Use of the International Criminal Court: Rebranding the State: Uganda and the ICC' (2015) 46 Development and Change 293.

Gaeta P, 'Is the Practice of “Self-Referrals” a Sound Start for the ICC?' (2004) 2 Journal of International Criminal Justice 949.

Gissel LE, ‘A Different Kind of Court: Africa's Support for the International Criminal Court, 19932003' (2018) 29 European Journal of International Law 725.

Helfer LR and Showalter AE, 'Opposing International Justice: Kenya's Integrated Backlash Strategy against the ICC' (2017) 17 International Criminal Law Review 1.

Heller KJ, 'Article 18 and the Iraq Declination' (Aralık 2020) <http://opiniojuris.org/2020/12/12/ article-18-and-the-iraq-declination/>

- 'The Nine Words That (Wrongly) Doomed the Iraq Investigation' (Arallk 2020) $<$ http:// opiniojuris.org/2020/12/10/the-nine-words-that-wrongly-doomed-the-iraq-investigation/>

Human Rights Watch, 'ICC: Investigate All Sides in Uganda' (ubat 2004) <https://www.hrw.org/ news/2004/02/04/icc-investigate-all-sides-uganda>

_ _ 'ICC: New Prosecutor Takes Reins' (13 June 2012) <https://www.hrw.org/news/2012/06/13/ icc-new-prosecutor-takes-reins>

Keller LM, 'The Practice of the International Criminal Court: Comments on the Complementarity Conundrum' (2010) 8 Santa Clara Journal of International Law 199.

Kılıç AS, 'Uluslararası Ceza Mahkemesi ve Devletlerin Egemenliği Üzerine Ulusal Egemenlik Odaklı Bir İnceleme’ (2009) 58 Ankara Üniversitesi Hukuk Fakültesi Dergisi 615.

Labuda PI, 'The International Criminal Court and Perceptions of Sovereignty, Colonialism and Pan-African Solidarity’ (2014) 20 African Yearbook of International Law Online 289. 
Lugano G, 'Counter-Shaming the International Criminal Court's Intervention as Neocolonial: Lessons from Kenya' (2017) 11 International Journal of Transitional Justice 9.

Moreno-Ocampo L, 'Keynote Address: Integrating the Work of the ICC into Local Justice Initiatives' (2006) 21 American University International Law Review 497.

Nation, 'Kagame Tells Why He Is Against ICC Charging Bashir' (Kigali, Ağustos 2008) $<$ https:// nation.africa/kenya/news/africa/kagame-tells-why-he-is-against-icc-charging-bashir--552248>

Nouwen SMH and Werner WG, 'Doing Justice to the Political: The International Criminal Court in Uganda and Sudan' (2010) 21 European Journal of International Law 941.

O'Brien M, 'Prosecutorial Discretion as an Obstacle to Prosecution of United Nations Peacekeepers by the International Criminal Court: The Big Fish/Small Fish Debate and the Gravity Threshold' (2012) 10 Journal of International Criminal Justice 525.

Otim M and Wierda M, 'Justice at Juba: International Obligations and Local Demands in Northern Uganda' in Nicholas Waddell and Phil Clark (eds), Courting Conflict? Justice, Peace and the ICC in Africa (Royal African Society 2008).

Roach SC, 'Legitimising Negotiated Justice: The International Criminal Court and Flexible Governance' (2013) 17 The International Journal of Human Rights 619.

Robinson D, 'The Controversy over Territorial State Referrals and Reflections on ICL Discourse' (2011) 9 Journal of International Criminal Justice 355.

Sã S and Cleary KA, 'The Gravity Threshold of the International Criminal Court' (2008) 23 American Journal of International Law 807.

Sagan A, 'African Criminals/African Victims: The Institutionalised Production of Cultural Narratives in International Criminal Law' (2010) 39 Millennium: Journal of International Studies 3 .

Salter M, Nazi War Crimes, US Intelligence and Selective Prosecution at Nuremberg: Controversies Regarding the Role of the Office of Strategic Services (1st edn, Routledge-Cavendish 2007).

Schabas WA, 'Prosecutorial Discretion v. Judicial Activism at the International Criminal Court' (2008) 6 Journal of International Criminal Justice 731.

Schabas WA, 'Victor's Justice: Selecting "Situations" at the International Criminal Court' (2010) 43 The John Marshall Law Review 535.

Schueller A, 'The ICC, British War Crimes in Iraq and a Very British Tradition' (Aralik 2020) $<$ http://opiniojuris.org/2020/12/11/the-icc-british-war-crimes-in-iraq-and-a-very-britishtradition/>

Smeulers A, Weerdesteijn M and Hola B, 'The Selection of Situations by the ICC: An Empirically Based Evaluation of the OTP's Performance' (2015) 15 International Criminal Law Review 1.

Sriram CL and Brown S, 'Kenya in the Shadow of the ICC: Complementarity, Gravity and Impact' (2012) 12 International Criminal Law Review 219.

Stahn C, 'Complementarity: A Tale of Two Notions' (2008) 19 Criminal Law Forum 87.

Stegmiller I, 'The Gravity Threshold under the ICC Statute: Gravity Back and Forth in Lubanga and Ntaganda' (2009) 9 International Criminal Law Review 547.

Takemura H, 'Big Fish and Small Fish Debate-An Examination of the Prosecutorial Discretion' (2007) 7 International Criminal Law Review 677.

Tiemessen A, 'The International Criminal Court and the Politics of Prosecutions' (2014) 18 The International Journal of Human Rights 444. 
Tillier J, 'The ICC Prosecutor and Positive Complementarity: Strengthening the Rule of Law?' (2013) 13 International Criminal Law Review 507.

Tladi D, 'The African Union and the International Criminal Court: The Battle for the Soul of International Law' (2009) 34 South African Yearbook of International Law 57.

Uluslararası Ceza Mahkemesi, Roma Statüsü (1998) <http://sorular.rightsagenda.org/Uploads/ UCM\%20MEV/Roma\%20Statüsü.pdf>

—_ 'Kongo Demokratik Cumhuriyeti Olayı’ Ön-Yargılama Mahkemesi Kararı, No: ICC-01/0401/07 (Şubat 2006) https://www.icc-cpi.int/RelatedRecords/CR2008_04184.PDF

_, 'Kongo Demokratik Cumhuriyeti Olayı' Temyiz Mahkemesi Kararı, No: ICC-01/04 (Ocak 2011) <https://www.icc-cpi.int/CourtRecords/CR2011_01426.PDF>

—, 'Regulations of the Office of the Prosecutor' (Nisan 2009) < https://www.icc-cpi.int/nr/ rdonlyres/fff97111-ecd6-40b5-9cda-792bcbe1e695/280253/iccbd050109eng.pdf>

_ , 'The Court Today', ICC-PIDS-TCT-01-114/20_Eng (Kasim 2020) <https://www.icc-cpi.int/ iccdocs/pids/publications/thecourttodayeng.pdf $>$

— Savc1lik Makam1, 'Policy Paper on the Interests of Justice' (Eylül 2007) <https://www.icc-cpi. int/nr/rdonlyres/772c95c9-f54d-4321-bf09-73422bb23528/143640/iccotpinterestsofjustice.pdf>

—, Savcilık Makam1, 'Prosecutorial Strategy 2009 - 2012' (Şubat 2010) <https://www. icc-cpi.int/NR/rdonlyres/66A8DCDC-3650-4514-AA62-D229D1128F65/281506/ OTPProsecutorialStrategy20092013.pdf >

— , Savc1lık Makam1, 'Policy Paper on Preliminary Examinations' (Kasım 2013) <https://www. icc-cpi.int/iccdocs/otp/otp-policy_paper_preliminary_examinations_2013-eng.pdf>

Uzun E, 'Milletlerarası Ceza Mahkemesi Düşüncesinin Tarihsel Gelişimi ve Roma Statüsü’ (2003) 2 Sosyal Bilimler Dergisi 25.

Verhoeven S, Wouters J and Demeyere B, 'The International Criminal Court's Office of the Prosecutor: Navigating between Independence and Accountability?' (2008) 8 International Criminal Law Review 273.

Vilmer J-BJ, 'The African Union and the International Criminal Court: Counteracting the Crisis' (2016) 92 International Affairs 1319.

Yigzaw DA, 'The International Criminal Court: Biased Against Africa or Weak Towards the Powerful?' (2017) 43 North Carolina Journal of International Law 204. 
